\title{
ФИЛОЛОГИЯ
}

DOI: 10.17805/ggz.2018.4.6

\section{Гамлет и Офелия как лирические герои в русской поэзии XIX-XX вв.}

О. И. Федотов

Независимый исследователь, 2. Москва

Статья посвящена достаточно традиционной в литературоведении проблеме активного функиионирования Гамлета и Офелии в ролевой русской лирике с начала ХІХ до кониа XX в. Основное внимание уделяется причинам обращения к этим хрестоматийным образам весьма не похожих друг на друга русских поэтов - от Н. А. Некрасова до И. А. Бродского, субъектной организации лирического дискурса, родовой и жанрово-видовой специфике соответствующих текстов, их индивидуально-стилевым и, прежде всего, стихопоэтическим (версификационным) особенностям.

Ключевые слова: У. Шекспир; Гамлет; Офелия; стихопоэтика; А. А. Блок; В. Я. Брюсов; М. И. Цветаева; А. А. Ахматова; Б. Л. Пастернак; И. А. Бродский

\section{Hamlet and Ophelia as Lyrical Heroes in 19th and 20th Century Russian Poetry \\ O. I. Fedotov \\ Independent researcher, Moscow}

The article deals with rather traditional problem for literary studies - that of active functioning of Hamlet and Ophelia in role-based Russian poetry from the early 19th to the late 20th century. The author focuses on reasons why quite different Russian poets (from N. A. Nekrasov to I. A. Brodsky) employed references to these iconic characters in their works. He also examines the subjective organization of lyrical discourse, generic and genre-specific features of the respective texts, their individual stylistic and, above all, verse poetical (versificative) characteristics.

Keywords: W. Shakespeare; Hamlet; Ophelia; verse poetics; A. A. Blok, V. Ya. Bryusov, M. I. Tsvetaeva, A. A. Akhmatova, B. L. Pasternak, I. A. Brodsky 
Феномен Русского Шекспира, не менее впечатляющий, чем его английский прообраз, центральная во всех отношениях трагедия Шекспира «Гамлет», в которой автор, можно сказать, солидарно с заглавным персонажем воссоздает максимально личностную картину мира, и два ее главных лица, Гамлет и Офелия, получившие в русской поэзии необычайную популярность как полнокровные лирические герои, - все это безусловно является предметом научного исследования в свете идей Вл. А. Лукова о тезаурусном подходе к изучению русской литературы в контексте мировой (Луков, 2006).

$$
* * *
$$

Среди не столь уж многочисленных сонетов М. И. Цветаевой особое место занимает, пожалуй, самый неканонический его вариант с не совсем обычным, вызывающе драматургическим заголовком: «Диалог Гамлета с совестью»:

— На дне она, где ил

И водоросли... Спать в них

Ушла, — но сна и там нет!

- Но я ее любил,

Как сорок тысяч братьев

Любить не могут! - Гамлет!

На дне она, где ил:

Ил!.. И последний венчик

Всплыл на приречных бревнах...

— Но я ее любил

Как сорок тысяч... - Меньше,

Все ж, чем один любовник.

На дне она, где ил.

- Но я ее любил??

5 июня 1923 г.

Перед нами текст необычный во всех отношениях. Лирическое стихотворение без привычного лирического героя. Диалог в чистом виде без малейшего намека на авторскую режиссуру. Сонет по числу строк, рифмующихся, однако, весьма нетрадиционным образом, выполненный совершенно

\footnotetext{
${ }^{1}$ Ссылки на стихотворные произведения М. И. Цветаевой здесь и далее даются непосредственно в тексте по изданию 1965 г. (Цветаева, 1965) с указанием страниц в круглых скобках.
} 
немыслимым для сонетного канона 3-стопным ямбом, деформированный к тому же фирменными цветаевскими анжамбманами и паузами на тире.

Разумеется, он уже не раз подвергался литературоведческому анализу в самых разнообразных аспектах: в связи с породившей его трагедией Шекспира, интерпретацией образов Гамлета и Офелии Цветаевой в «Диалоге» и трех других циклизующихся с ним стихотворениях «Офелия - Гамлету», «Офелия - в защиту Королевы», «Свиданье», его жанровой спецификой и особенностями художественной структуры, интертекстуальным взаимодействием с аналогичными произведениями предшественников в европейской и отечественной поэзии. Но, наверное, таково свойство вечных образов вообще - вечно привлекать к себе повышенное внимание, искушать бессчетное количество раз проходить по проторенным тропам в поисках наиболее адекватной и аргументированной их трактовки.

\section{1.}

Насколько вообще свойственна лирике диалогическая форма? Корни лирических диалогов нужно искать, конечно, в античности. В долитературных народных песнях, к примеру, эллинские девушки танцевали вокруг избранной по жребию «черепахи» («хели»), поочередно задавая ей вопросы, на которые она должна была отвечать:

— Черепаха-пряха, что творишь в кругу?

- Из шафрана милетского шарф я тку.

- Как погиб, открой, этот отпрыск твой?

- Сел на бела коня, да и море плашмя.

(Хелихелина / пер. Я. Э. Голосовкера) $(31)^{2}$

Насквозь диалогичной была и мелика уроженцев острова Лесбоса Алкея и Сапфо, отважно, во всеуслышание обменявшимися, один - пылким любовным признанием: «Сапфо, фиалкокудрая, чистая, / С улыбкой нежной! Очень мне хочется / Сказать тебе кой-что тихонько, / Только не смею: мне стыд мешает» (36), другая - суровой отповедью: «Когда б твой тайный помысл невинен был, / Язык не прятал слова постыдного, — / Тогда бы прямо с уст свободных / Речь полилась о святом и правом» $(70)^{3}$ на одном и том же строфическом языке (Алкеевой строфой).

В своих ударных любовных гимнах Сапфо охотно вступает в диалог то с Афродитой («Гимн Афродите»), то с подругой («Гонгиле»), используя кро-

\footnotetext{
2 Здесь и далее произведения античной лирики цитируются по изданию «Античная лирика» (Античная лирика, 1968) с указанием страниц в круглых скобках.

${ }^{3}$ Оба перевода выполнены В. В. Вересаевым.
} 
ме прямой речи вводящие ее модальные конструкции: «Мне Гонгила сказала: “Быть не может! / Иль виденье тебе / Предстало свыше?” // “Да, — ответила я, - Гермес - / Бог спустился ко мне во сне. К нему я: / "О владыка, взмолилась, - / Погибаю. / Но клянусь...» (пер. Я. Э. Голосовкера) (59-60).

Популярнейшая строфическая и одновременно метрическая форма античной лирики элегический дистих, по мнению И. А. Бродского, вообще была как бы специально приспособлена к риторической (диалогической) системе мышления древних греков. Элегическое двустишие, предполагал он, «давало возможность выразить как минимум две точки зрения, не говоря уже обо всей палитре интонационной окраски, обеспечиваемой медлительностью гекзаметра и функциональностью пятистопного ямба ${ }^{4}$ с его дактилической то есть отчасти рыдающей, отчасти самоустраняющейся второй половиной» (Бродский, 1991: 38) ${ }^{5}$ :

Золото этот нашел, а тот потерял его. Первый Бросил сокровище прочь, с жизнью покончил второй.

(Платон / пер. О. Б. Румера) (195)

Весьма диалогичны были любовные бейты и в средневековой арабской поэзии; вот, к примеру, диалог отца с дочерью на вечную, как мир, тему замужества:

«Двое сватов прислали, - сказал мне отец, -

Оружейник-бедняк и сосед наш купец.

Хоть не молод купец, но он щедр и богат, Он жене молодой угождать будет рад.

Ты ведь любишь наряды - и шелк и парчу, Не упрямься — отдам я тебя богачу».

Не сердись, мой отец, - если все решено, Значит, век мне с купцом горевать суждено.

Хоть и знаю, что жизнь с бедняком не легка, Легче бедность терпеть, чем любовь старика.

(Аль-Газаль. Пер. Б. Я. Шидфар; цит. по: Арабская поэзия ..., , 1975: 550).

\footnotetext{
${ }^{4}$ Видимо, оговорка, или, скорее, обратный перевод с английского; должно быть - пентаметра.

${ }^{5}$ Подробнее см.: Федотов, 2002: 26.
} 
Нередко также на диалогической основе строил свои рубаи Омар Хайам. Диалог мог идти как между разными лицами, так и внутри самого лирического героя:

Просило сердце: «Поучи хоть раз!»
Я начал с азбуки: «Запомни — «Аз».
И слышу: «Хватит! Все в начальном слоге,
А дальше — беглый, вечный пересказ».

(Пер. И. И. Тхоржевского; Хайам, 2005: 39)

В Средние века в рыцарской лирике трубадуров, труверов и миннизингеров культивировался весьма специфический жанр тенсоны, песни-спора, прений. Видимо, он развился как отдаленный отголосок упомянутых античных традиций, их арабских аналогов, а также как модификация обмена любезностями между двумя жонглерами, приглашающими почтенную публику к поэтическому действу. Обычно это были произведения, написанные двумя соавторами. Предметом их поэтического спора могли быть проблемы политические, философские, этические, бытовые (например, какой вид любви предпочтительнее), вопросы поэтической техники и стиля (например, тенсона сторонников «ясного» и «темного» стилей Гираута де Борнеля и Раймбаута III, графа Оранского) - словом, все, что угодно, вернее, все, что так или иначе волновало людей рыцарского круга (Федотов, 2011а: 80-81).

Обмениваться репликами могли и лирические персонажи пастурелл, либо в сопровождении авторского голоса: «К ней обратился тогда я: / - Милочка! Буря какая / Нынче взметается злая! / — Дон! отвечала девица, — / Право, здорова всегда я, / Сроду простуды не зная, - / Буря пускай себе злится!», либо без него, в строгом чередовании «персональных» строф, открывающихся соответствующим обращением: «Милочка!» и «Дон!», вплоть до заключительной «посылки», завершающей диалог: «- Милочка! Вы загляденье! / Полно же без сожаленья / Так над любовью глумиться. // — Дон! Нам велит Провиденье: / Глупым — ловить наслажденье, / Мудрым - к блаженству стремиться!» (Маркабрю / пер. В. А. Дынник; Поэзия трубадуров ..., 1974: 42-44).

Подобного рода любовные прения, но уже на другом, социально более высоком уровне, между знатной «донной» и, по крайней мере, равным ей «другом» представляет собой стихотворение, приписываемое легендарной графине де Диа, известной исключительно по «биографиям» трубадуров. Череда персонифицированных строф, содержащих взаимные укоры и жалобы на уязвимость своей позиции в любовном поединке, завершается в посылке обоюдным согласием и полной гармонией: «- Мой друг, после клятвы такой 
/ Я вновь обретаю покой! / - Да, Донна, храните покой: / Одна вы даны мне судьбой» (там же: 78).

Удивительным образом близким по духу цветаевскому «Диалогу» оказался шедевр стихотворений такого рода, созданный в переломную эпоху от Средневековья к Ренессансу «Спор в форме баллады меж телом и сердцем Вийона»:

— Кто там стучит? - Я. - Кто ты? - Сердце я,

Которое живет в груди твоей

И, видя, что без пищи и питья

Ты чахнешь, пса бездомного бедней,

Тебя жалеет что ни год сильней.

- Что я тебе? - Ты вздор несешь страшенный:

Ведь мы же нераздельны совершенно.

— Дай мне подумать. Жди. - И долго ль ждать?

- Пока я в возраст не войду степенный.

- Тогда смолкаю я. - А мне плевать.

(Пер. Ю. Б. Корнеева; Вийон, 1998: 402)

В дальнейшем, особенно в Новое время традиция драматургической диалогизации лирики стала весьма продуктивной. Укажем лишь на самые яркие прецеденты: «Пролог в театре» к «Фаусту» И.-В. Гёте, где разговор о готовящемся спектакле и о театральном искусстве в целом ведут три в общемто лирических персонажа: Директор, Комический актер и Поэт; сатиры А. Д. Кантемира «Сатира I. На хулящих учения. К уму своему», в котором прямо или косвенно участвует несколько аллегорических персонажей (Критон, Силван, Лука, Медор и др.), и «Сатира II. На зависть и гордость дворян злонравных» ${ }^{6}$, доверенная двум демонстративно дискутирующим персонажам; наконец, прямо и недвусмысленно названный М. В. Ломоносовым как жанр «Разговор с Анакреонтом», где автор дискутирует с античным поэтом, отвечая на несколько его концептуальных од. Последний пример оказался для отечественной поэзии весьма заразительным. Этические и эстетические «разговоры» мы находим в творчестве Пушкина, Лермонтова, Некрасова вплоть до Маяковского и Цветаевой.

\section{2.}

Наконец, еще одна в высшей степени оригинальная особенность жанровой структуры цветаевского диалога состоит в том, что это не просто ли-

\footnotetext{
${ }^{6}$ В авторском комментарии о ней сказано: «Писана она месяца два спустя после первой, разговором между Филаретом и Евгением - два подложные имена, которых первое на греческом языке изобразует любителя добродетели, а другое - дворянина» (Кантемир, 1956: 77; курсив источника. - О. Ф.).
} 
рическое стихотворение с ярко выраженным драматургическим элементом, но еще и сонет, пусть и далеко не классический.

Сонет - уникальное жанровое образование, впитавшее в себя конструктивные признаки всех трех родов литературы. Главным образом, конечно, это идеальный способ художественного воплощения лирической медитации, не исключающий, однако, эпического и драматургического дискурca.

Активное сотрудничество сонета с драмой выражается в свойственной ему диалогической (и шире - полилогической) природе, в способности интертекстуального взаимодействия автора и реципиента, лирических героев (Я и Ты, Он и Она, а также разных иных местоименных форм, и - не в последнюю очередь — конкретно поименованных персонажей), автора данного сонета и его собеседников в прошлом, настоящем и будущем (сонеты о сонетах, обмен сонетами: sonetto di proposta и sonetto di risposta) или всякого рода соревнования в режиме буриме.

Особняком стоит внедрение сонетов в собственно драматургическую ткань. Самый хрестоматийный пример - сонет в Прологе «Ромео и Джульетты» Шекспира: «Две равно уважаемых семьи...» (в пер. Б. Л. Пастернака). Точно так же, вслед за ним, поступил П. Кальдерон, все дошедшие до нас сонеты которого извлечены из его пьес. Например, сонетами «Казались сада гордостью цветы...» и «Рассыпанные по небу светила...» (в пер. Б. Л. Пастернака) обмениваются персонажи «Стойкого принца» Фернандо и Феникс. Только искушенный знаток различит сонет, который вложил в уста пана Мнишка А. С. Пушкин в своем «Борисе Годунове»: «Мы, старики, уж нынче не танцуем...» (Shaw, 1991; Шоу, 1994; Хворостьянова, 2008: 193-195; Шайтанов, 2003).

Впрочем, в данном случае о сонетном достоинстве зарифмованного высказывания Мнишка приходится судить гипотетически: во-первых, он не актуализирован ни номинально (не назван таковым), ни графически (не обособлен в тексте), ни драматургически (монолог персонажа переходит в диалог), к тому же с ответной репликой Вишневецкого набирается «лишняя» 15-строка: «Пойдем же, брат. / Вишневецкий / И дело, друг, пойдем» (Пушкин, 1995: 57). Таким образом, полученное 15-стишие впору рассматривать как аномальный сонет с кодой. Пушкин же, как известно, хотя и не был чужд формальному эксперименту, более тяготел к консервативно-классической традиции. Недаром Б. В. Томашевский называл его «классиком в строгом смысле этого слова» (Томашевский, 1990: 300). Поэтому и сонетами для него были сонеты как таковые, а не их дериваты. 
В насквозь диалогизированной системе книги сонетов А. Мицкевича элементы драмы проявляют себя в высшей степени активно, концептуально и разнообразно. I-я и II-я части сборника «Sonety», изданного в типографии Московского университета в 1826 г., вступают в диалогические отношения друг с другом прежде всего по своей жанровой и тематической принадлежности. I-я часть, насчитывающая 18 сонетов, может быть условно названа «Любовными сонетами», II-я, состоящая из 22 сонетов, имеет официальное, авторское название - «Sonety Krymskie». В результате интимная лирика противостоит гражданской; родной, польский хронотоп - изгнанническому, крымскому; ориентация на сонеты Ф. Петрарки - патриотическому пафосу И.-В. Гёте. Разделив свою книгу на два тематически обособленных цикла, Мицкевич сам вступает в творческий диалог с предшественниками (Петраркой) и увлекает за собой своих польских и русских почитателей. Перекличку с корифеями прямо и недвусмысленно актуализируют прежде всего эпиграфы. I-ю часть предваряет строка 1-го сонета 1-й же части «Книги песен» Петрарки «Quand'era in parte altr’uom da quell ch'i’sono» («Когда отчасти был другим, чем ныне человеком») не только отсылает к первоисточнику, но и намекает на прошедшее время событийного плана и соответствующий характер лирических переживаний, так сказать, «post factum». II-ю часть предваряет цитата из «Западно-восточного Дивана» И.-В. Гёте: «Wer den Dichter will verstehen, / Muß in Dichters Lande gehen» («Кто хочет постичь поэта, / Должен отправиться в страну поэта»), устанавливающая ассоциативные связи с ориентальными мотивами современного мастера и с горькой иронией определяющая ситуацию, в которой оказался отнюдь не по своей воле автор.

Другой, не менее характерный элемент драматургической структуры обнаруживается в уникальном сонете «Widzenie sie w gaju» («Свидание в роще»), лирический герой которого полностью объективируется как участник ночного приключения и драматизированного диалога.

Сонет представляет собой диалог в чистом виде. Репликами обмениваются молодые люди, встретившись ночью в роще. Несмотря на предельно ограниченный временной промежуток художественно запечатленного события (самые первые мгновения свидания), в диалоге угадываются не только основные перипетии сюжета, но и некоторые из его канонических элементов. Роль лирической экспозиции берет на себя заголовок, фиксирующий ситуацию и место действия, словом, заключает в себе весь нарратив: «Widzenie sie w gaju» - «Свидание в роще». Событийный план восстанавливается по репликам персонажей. Авторского повествования, ремарок и даже обозначения действующих лиц в тексте нет. 
Совершенно иную картину мы видим в «Крымских сонетах». В шести сонетах, таких как: V. «Widok gór ze stepów Kozłowa. Pielgrzym i Mirza» («Вид гор из степей Козловских. Пилигрим и Мирза»), IX. «Mogiły Haremu. Mirza do Pielgrzyma» («Могилы гарема. Мирза Пилигриму»), XIII. «Czatyrdah. Mirza» («Чатырдаг. Мирза»), XIV. «Pielgrzym» («Пилигрим»), XV.«Droga nad przepaścią w Czufut-Kale. Mirza i Pielgrzym» («Дорога над пропастью в Чуфут-Кале. Мирза и Пилигрим»), XVI. «Góra Kikineis. Mirza» («Гора Кикинеиз. Мирза»), имена персонажей входят в состав заголовков или, чаще, подзаголовков; причем в одном случае выступают в их роли целиком (XIV), в другом еще дополнительно устанавливают адресата и адресанта высказывания (IX), отчасти выполняя функцию авторской ремарки.

Как и в любовных сонетах, во II-й части фигурируют два основных лирических персонажа: Пилигрим и Мирза, медитирующие обособленно или дуэтом. В контексте всего цикла, это как бы раздвоившийся лирический герой, диалогизирующий сам с собой или, скорее, принимающий разные точки зрения. Первый максимально приближенный к биографической личности поэта-изгнанника, путешествующего с друзьями по экзотической крымской земле, наделен ярко выраженными чертами цивилизованного европейца, человека, тоскующего по родине и в то же время с благодарностью впитывающего яркие впечатления от увиденного и пережитого. Второй - человек восточного менталитета, правоверный мусульманин, открывающий своему европейскому спутнику специфику реальных и мифологических представлений аборигенов. Оба стремятся примениться друг к другу, размышлять в унисон, поэтому их речевые манеры не слишком различны.

Показательно, что сонеты, содержащие словесные партии обоих лирических персонажей, группируются практически подряд: V, IX, XIII-XVI. Они образуют некий сквозной сюжет, основанный на стереоскопической презентации Крыма, с его природой и обитателями, как некоего пространства, наполненного романтической экзотикой, бесконечно далекого от родины лирического героя.

Не была чужда тенденции включения сонетов в состав своих драматургических произведений и М. И. Цветаева. Так, блестящий ее сонет «Проклятие тебе, что меч и кубок...», написанный якобы экспромтом прославленным авантюристом и сердцеедом Казановой, оказался в составе ее поэтической драмы «Феникс», датированной июлем - августом 1919 г., как искусственный прием, иллюстрирующий, кроме того, давнюю традицию поэтических турниров и заодно раскрывающий идейный пафос всего произведения (Федотов, 2011b: 333-340). 
3.

М. И. Цветаева была не слишком предрасположена к сонетам, как, впрочем, и к твердым строфическим формам вообще. Ее необузданному дару строфы с регламентированной, неукоснительно соблюдаемой структурой были просто противопоказаны. Большую часть четырнадцатистиший в ее исполнении составляли нетрадиционные дериваты сонетов. «Диалог Гамлета с совестью» можно квалифицировать как аномальный сонет с неканонической рифмовкой, наполовину сплошной, наполовину тавтологической на мужских позициях.

В принципе, сочетаются четыре цепных, попарно взаимодействующих терцета с финальным двустишием. Перед нами довольно редкая строфическая модель, синтезировавшая удвоенную терцетную часть итало-французского канона с кодой английского сонета, что соответствует и тематической композиции стихотворения.

Обозначенная в заголовке установка на диалогичность лишний раз подтверждает правоту П.Г. Антокольского, усомнившегося в неприятии Цветаевой театральности, о которой она с присущим ей ригоризмом заявила в предисловии к своей пьесе «Конец Казановы»: «Не чту Театра, не тянусь к Театру и не считаюсь с Театром. Театр (видеть глазами) мне всегда казался подспорьем для нищих духом, обеспечением для хитрецов породы Фомы Неверного, верящих лишь в то, что видят, еще больше: в то, что осязают. - Некой азбукой для слепых.

А сущность Поэта — верить на слово!» (Цветаева, 1922; 1991: 259).

Приведя эти слова, П. Г. Антокольский возражает: «Не слишком я верю этому отречению от театра! Я был свидетелем противоположной - трогательной тяги Марины Ивановны Цветаевой к театру, к молодому авторскому коллективу, к ученикам Евгения Багратионовича Вахтангова, к маленькой сцене в Мансуровском переулке на Остоженке в 1918-1920 годах» (Антокольский, 1988: 5).

Однако прислушаемся к высказыванию Цветаевой внимательнее. О чем она говорит? О театре как зрелище, апеллируя к внутренней форме греческо-

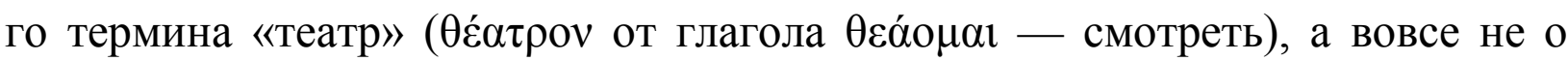
драматургии как литературном роде или о театре как культурном учреждении. Поэта не устраивает видимая и осязаемая конкретность театрального представления (собственно зрелища), а не драматургический способ образного мышления. Она вообще мало доверяла своему зрению, кстати, довольно слабому, как в жизни, так и в творчестве. Гораздо более достоверную картину мира ей удавалось воссоздать интенсивной работой духа - воображением. Ее пьесы, в том числе и по этой причине, ни в коем случае не были пред- 
назначены для сцены. Это не театр, а поэзия в драматургической форме. Не станем же мы разыгрывать по ролям условные диалоги - «разговоры» Державина с Анакреонтом, Пушкина с Книгопродавцем, или, положим, пушкинских же «Цыган», да по большому счету и - «Фауста» Гёте!

Таковы же, если не в большей мере, цветаевские циклы «Стенька Разин» «Гаданье» (1917), «Комедьянт» (1918), «Бабушка» (23-25 июля 1919), «Разговор с Гением» (4 июня 1928); не говоря уже о том, что большую часть ее лирических произведений составляют ярко выраженные обращения к ярко выраженному адресату, т. е. тоже, в конечном счете, драматургические монологи. В этом же ряду находятся два ее канонических сонета «Как жгучая, отточенная лесть...» (29 сентября 1915), - скрытый диалог с автором «Ars Amandi» Овидием, и сонет Казановы, включенный в драматургическое действие пьесы «Феникс», внутри которого также слышится страстный диалог состарившегося повесы с подступающей смертью. Таков же, как нам предстоит убедиться, дериват сонета «Диалог Гамлета с совестью».

На этот раз Цветаева обращается едва ли не к самому знаменитому шекспировскому персонажу, сконтаминировав его концептуальный монолог «Быть иль не быть...» из 1-й сцены 3-го акта и сцену прощания с Офелией на кладбище в начале 5-го акта. По всем правилам театрального искусства лирическая медитация принимает диалогическую форму, распадается на реплики. С кем, однако, диалогизирует Гамлет? Или с обозначенным в заголовке аллегорическим персонажем, которого нет в списке действующих лиц шекспировской пьесы? Или, может быть, с собственным alter ego, если допустить, что внутри нас, в нашем сознании живет некий сокровенный нравственный контролер, оценивающий наши поступки и помыслы по беспристрастному гамбургскому счету? И в обоих случаях имя ему - Совесть.

Цветаева не идет за Шекспиром след в след. В художественном мире его бессмертной трагедии она выстраивает собственный альтернативный сюжет, причем изначально не в одном, а в трех циклизующихся друг с другом лирических пьесах ${ }^{7}$. До «Диалога» гамлетовские мотивы прозвучали еще в двух обращениях Офелии к Гамлету: «Офелия - Гамлету» («Гамлетом перетянутым - натуго...») и «Офелия — в защиту Королевы» («Принц Гамлет! Довольно червивую залежь...»). Оба стихотворения написаны в один день - 28 февраля 1923 г.

Рассматривая эти две преамбулы к «Диалогу...», можно констатировать, что Цветаева выбирает своим лирическим конфидентом не заглавного героя Гамлета, который, как справедливо считают шекспироведы, был ближе

\footnotetext{
${ }^{7}$ В первых публикациях этот лирический триптих составлял единый цикл «Гамлет» (За-
} писки наблюдателя, 1924: 15-16). 
всего личности его создателя, а преданную ему и преданную им Офелию, решительно переиначивает ее характер, поставив себя на ее место, вернее, придав ей черты своей лирической героини. В первом случае ее монолог являет собой гневную инвективу против героя, увлеченного самоубийственным пафосом безумного стремления в одиночку вправить «вывихнутый мир» и не заметившего такой малости, как любовь наивной, чистой, очарованной им девушки, мало того, отождествившего свою возлюбленную с предавшей память об отце матерью, заподозрившего в ней коварство, присущее женщинам вообще, и спокойно переступившего через нее:

Девственник! Женоненавистник! Вздорную

Нежить предпочедший!.. Думали ль

Раз хотя бы о том - что́ сорвано

В маленьком цветнике безумия...

К голосу Офелии примешиваются голоса символических роз, из которых обезумевшая героиня плела свой предсмертный венок и которые от имени всех погубленных таким же образом ее подруг по несчастью, в прошлом, настоящем и будущем, взывают о возмездии (к совести?):

$$
\begin{aligned}
& \text { Розы?.. Но ведь это же — тсс! — Будущность! } \\
& \text { Рвем — и новые растут! Предали ль } \\
& \text { Розы хотя бы раз? Любящих - } \\
& \text { Хотя бы раз? - Убыли ль? } \\
& \text { Выполнив (проблагоухав!), тонете... } \\
& \text { — Не было! — Но встанем в памяти } \\
& \text { В час, когда над ручьевой хроникой } \\
& \text { Гамлетом — перетянутым — встанете... }
\end{aligned}
$$

Во втором случае Офелия выступает с по-цветаевски неистовой апологией королевы Гертруды, его матери, безоглядно отдавшейся поразившей ее страсти. В ее экстатической речи взахлеб отнюдь не случайно путаются формы единственного и множественного числа: «...На розы взгляни! / Подумай о той...» (222) и «...А вы с вашей примесью мела / И тлена... С костями злословь, / Принц Гамлет! Не вашего разума дело / Судить воспаленную кровь» (223), нагнетаются анафорические обращения: «Прини Гамлет!» в зачине двух первых катренов и во втором стихе третьего, резкие анжамбеманы в синтаксических параллельных конструкциях: «Довольно червивую залежь / Тревожить... На розы взгляни!» (222), «Довольно царищьны недра / Порочить ... Не девственным - суд / Над страстью. Тяже́ле виновная - Федра: / О ней и поныне поют» (223), эллиптические пропуски связующих слов, мар- 
кируемые характерными тире или многоточиями: «Подумай о той, что $<$ ради> единого дня лишь — / Считает последние дни» (222) «Не девственным <мужчинам производить > - суд / Над страстью» (223). Все перечисленные приметы, столь характерные для идиостиля Цветаевой, лишний раз убеждают нас в том, что, оставив от шекспировской героини лишь имя, Цветаева властно берет творческую инициативу в свои руки и обращается к Гамлету, также, кстати, своевольно переосмысленному, от лица своей лирической героини:

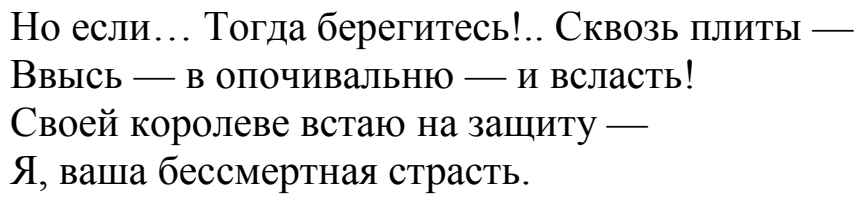

Такого рода обращение вглубь веков равным образом напоминает обращения к персонажам античной мифологии Ариадне и Эвридике, к главным героям расиновской «Федры», к Гомеру («Двое»), к поэтам XIX века «Стихи к Пушкину», к К. Н. Батюшкову («Я берег покидал туманный Альбиона...»), а также к современникам «Стихи к Блоку», «Из цикла “Ахматовой”», «Маяковскому», к Б. Л. Пастернаку («Рас-стояние: версты, мили...»), к Р. М. Рильке, наконец... на тот свет («Новогоднее»).

\section{4.}

Но вернемся к основному предмету нашего исследования.

Второго участника лирического диалога в нем - Совесть М. И. Цветаева, можно предположить, отыскала в душе конгениального его создателю заглавного героя трагедии или в мотивном комплексе этого ультрафилософского произведения, ибо муки совести терзают практически всех основных героев: Клавдия, Гертруду, Полония, Лаэрта, даже Офелию... Склонного же к рефлексии Гамлета - в первую очередь. Могли быть, однако, причины и чисто лингвистического свойства. Слово “conscience” фигурирует в тексте трагедии семь раз:

1) 84-й стих 3-го акта 1-й сцены: "Thus conscience does make cowards <of us all>” три далеко не периферийных переводчика трактовали по-русски следующим образом:

«Такъ робкими творитъ всегда насъ совъсть» / пер. М. П. Вронченко «Так всех нас совесть обращает в трусов» / пер. А. И. Кронеберга «Как совесть делает из всех нас трусов» / пер. К. Р. 
Другие переводчики актуализировали в слове “conscience” не прямое значение, а иные связанные с ним семантические обертоны: «сознанье» (Д. В. Аверкиев, И. В. Пешков), «раздумье» (М. Л. Лозинский), «мысль» (Б. Л. Пастернак), «бледная мысль» (А. Д. Радлова), «абстрактное мышленье» (В. Р. Поплавский), «бледный свет размышленья» (В. Н. Рапопорт).

2) В рифмованной концовке 2-го акта, задумав, как изобличить убийцудядю, Гамлет восклицает:

More relative than this, the play's the thing

Wherein I'll catch the conscience of the king.

Вот как перевели финальное двустишие упомянутые переводчики:

«Мне нужны доказательства прямее: / Я совесть дяди сценой уловлю» (Аверкиев); «Изъ представленья я устрою пасть - / Въ нее должна убійцы совъсть впасть» (Вронченко); «Злодею зеркалом пусть будет представленье, / И совесть скажется и выдаст преступленье» (Кронеберг); «<..> Вернее той. Поставлю драму я, / Чтоб уловить в ней совесть короля» (К. Р.); «Тем представленьем сеть закину я, / Чтоб изловить мне совесть короля» (Радлова); «Верней опора. Зрелище - петля, / Чтоб заарканить совесть короля» (Лозинский); «Чтоб совесть короля на нем суметь / Намеками, как на крючок, поддеть» (Пастернак); «Поймать в ловушку совесть короля / Своею пьесою надеюсь крепко я» (Рапопорт).

Из всех задействованных нами переводчиков, только В. Р. Поплавский и И. В. Пешков отказались от упоминания совести: первый проигнорировал ее вовсе, второй заменил «мыслями»: «Поможет пьеса мне - и, текст кроя, / В нее поймаю мысли короля».

3) В 5-й сцене 4-го акта, ст. 136, о совести в своем «гигантском мятеже» вспоминает Лаэрт:

Conscience and grace, to the profoundest pit!

В передаче на русский язык занимающего нас слова большинство переводчиков избирает корневую сему «совести» и только М. Л. Лозинский, Б. Л. Пастернак и И. В. Пешков находят другие эквиваленты:

«И совъсть, / И благодать въ бездонную пучину!» (Аверкиев); «Во глубь геенны, совъсть, добродътель!» (Вронченко); «Смиренье, совесть - в глубочайший тартар!» (Кронеберг); «Во тьму кромешную, благоговенье, совесть!» (К. Р.); «И в преисподнюю страх божий! Совесть!» (Радлова); «В геенну верность! Клятвы к черным бесам! / Боязнь и благочестье в бездну бездн!» (Лозинский); «И преданность и верность шлю к чертям» (Пастер- 
нак); «Мне наплевать на верность и на долг. / В болото набожность и к черту совесть» (Поплавский»); «Послал к чертям я верность и присягу, / На свалку выбросил и благодать, и совесть» (Рапопорт); «В ад преданность и к дьяволу все клятвы! / Долг и добро - все в яму и поглубже!» (Пешков).

4) Здесь же, в самом начале 7-й сцены 4-го акта, ст. 1, существительное “conscience” всплывает в увещевательной реплике Клавдия, исподволь готовящего Лаэрта к предательской мести:

Now must your conscience my acquaintance seal...

В данном контексте мнения переводчиков разделились практически поровну: сначала все дружно актуализировали нравственный аспект, пользуясь значением «совести»; более поздние авторы апеллируют скорее к «сердцу» и «сознанью»:

«Теперь, Лаэртъ, и ваша совесть можеть / Къ моей уплате приложить печать» (Аверкиев); «Теперь твоя жъ запечатлЂеть совъсть / Мою невинность и повърить дружбђ...» (Вронченко); «Теперь, Лаэрт, ты принужден сознаться, / Что я не виноват...» (Кронеберг); «Твоею совестью я должен быть оправдан...» (К. Р.)»; «Теперь по совести должны, Лаэрт, / Меня вы оправдать и стать мне другом» (Радлова); «Теперь, мое скрепляя оправданье, / Ты должен в сердие взять меня как друга» (Лозинский); «Теперь ваш долг принять меня в друзья / И в сердие подписать мне оправданье» (Пастернак); «Ну вот, ты знаешь все и сам судить / Способен, виноват ли я...» (Поплавский); «Ты должен оправдать меня теперь / И в сердие поместить, как друга...» (Paпопорт); «Теперь в своем сознанье невиновность / Мою запечатлейте» (Пешков).

5-6) Практически подряд мотив совести дважды звучит во 2-й сцене 5го акта, ст. 60 и 70, когда в разговоре Гамлета с Горацио обнаруживается гибель Гильденстерна и Розенкранца, которая не вызывает сочувствия у главного героя, а затем тут же в его рассуждении о том, что подлый Клавдий достоин возмездия. Оба стиха также переведены не однозначно:

«Ихъ смерть мнғ совъсти не тяготитъ...», «...иль я не долженъ, съ полнымъ / Сознаніемъ, разсчесться съ нимъ своей / Рукой?..» (Аверкиев); «Они не близки къ сердиу мнъ, и сами / Накликали себъ пронырствомъ гибель...», «Что, не должно ль долгъ / Воздать ему рукой сей?..» (Вронченко); «Их смерть мою не потревожит совесть...», «с ним рассчитаться / Не вправе ли моя рука?» (Кронеберг); «Ведь сами назвались они на это дело / И совести моей не тронут...», «...не должен ли я с тем... / ...nо совести и праву / Своей разделаться рукою?» (К. Р.); «Что ж, по сердцу им было это дело. / Меня за 
них не укоряет совесть...», «Ведь, правда, дело совести - вот этой / Рукою отомстить?» (Радлова); «Они мне совесть не гнетут; их гибель / Их собственным вторженьем рождена», «Мне самому, — не правое ли дело / Воздать, ему вот этою рукой?» (Лозинский); «Меня не мучит совесть. Их конец — / Награда за пронырство», «И правда, разве б не было проклятьем / Дать этой язве дальше нас губить?» (Пастернак); «...а совесть / Моя чиста: я их предупреждал, — / Не надо было лезть в чужие игры» (Поплавский); «Но в этом деле совестью я чист...», «Я разве не имею права / За преступленья такие / С ним рассчитаться собственной рукой?» (Рапопорт); «...Ведь свои интриги, / Плели они себе же на погибель», «За подлость всю — не справедлива ль мысль / С ним расплатиться этою рукой?» (Пешков).

7) В последний раз слово “conscience” фигурирует у Шекспира в сцене роковой дуэли между Гамлетом и Лаэртом в 5-м акте, 312 ст., в реплике последнего (естественно, в сторону):

And yet 'tis almost 'gainst my conscience.

Здесь в переводе - полное единогласие - Лаэрт ощущает укор совести и сам себе признается в этом:

«Хотя меня тревожить / И начинаетъ совъсть...» (Аверкиев); «Хотя моя и сильно ропщеть совғсть...» (Вронченко); «Меня как будто совесть упрекает...» (Кронеберг); «Хоть совести моей оно противно...» (К. Р.); «Хоть это против совести моей...» (Радлова); «Почти что против совести, однако...» (Лозинский); «Хоть это против совести поступок...» (Пастернак); «А совесть мне предъявит счет потом...» (Поплавский); «И все же это почти что против совести...» (Рапопорт); «Почти что против совести все это...» (Пешков).

Таким образом, Совесть как видимый партнер для диалога с заглавным героем трагедии обнаруживает себя в ней вполне. Едва ли Цветаева знакомилась с текстом шекспировской пьесы на английском языке. Хотя она и переводила две народных баллады о Робин Гуде и Песню Стефано из второго акта драмы «Буря», прекрасно изучив в детстве французский и немецкий языки, английский она знала явно недостаточно, не в пример своей сестре Ace. Почти наверняка она читала Шекспира в русских переводах, в которых, как мы убедились, взыскующая «совесть», по крайней мере, в вербальном выражении мелькала довольно часто. 
5.

Анализируемый нами текст представляет собой диалог в самом чистом беспримесном виде. В нем слышится прямой обмен репликами без какихлибо модальных конструкций, хоть как-то локализующих или персонифицирующих лирическую экспозицию. Первая реплика принадлежит, как обозначено в заголовке, внутреннему голосу Совести: «- На дне она, где ил / И водоросли... Спать в них / Ушла, - но сна и там нет!» (240). Нет сомнения в том, что она перекликается с центральным монологом самого Гамлета, в котором смерть также метафорически сопрягается со сном: «...Умереть, уснуть. - Уснуть! // И видеть сны, быть может? Вот в чем трудность; // Какие сны приснятся в смертном сне...» ${ }^{8}$. Косвенным образом это может служить доказательством, что Совесть пребывает в сознании Гамлета, а не общается с ним как аллегорически обособленный персонаж вне его. Ожидаемого сна-успокоения Офелия не находит и на том свете («на дне»), т. е., надо понимать, и в «смертном сне» ей не забыться, не уснуть. Потому, видимо, в конце своего монолога Гамлет находит возможным обратиться к ней: «Но тише! / Офелия? - В твоих молитвах, нимфа, / Все, чем я грешен, помяни».

Ответная реплика Гамлета переносит нас на эльсинорское кладбище, возвращает к спору заглавного героя с братом погибшей. Его довод с эффектной гиперболизированной синекдохой: «Ее любил я; сорок тысяч братьев / Всем множеством своей любви со мною / Не уравнялись бы» почти дословно преподносится на рандеву с собственной совестью. Важно отметить, что в трактовке Цветаевой он вводится союзом «но» с модальностью частичного согласия и морального оправдания: «- Но я ее любил, / Как сорок тысяч братьев / Любить не могут!» и что последний стих обрывается на разрыве последней стопы. Причем возникший в результате глубокий ритмический перебой подчеркивается не только синтаксически, но и графически, и, следовательно, интонационно. 6-й стих распадается на две ступеньки, одна из которых фиксирует фразу Гамлета, а другая начало повторного укора Совести: «Гамлет! // На дне она, где ил...».

Обвинительный вердикт совести и оправдание любовью Гамлета в разных, однако, вербальных и версификационных вариантах повторяются трижды. Отсюда - демонстративное обилие тавтологических рифм, нагнетающих экспрессию, и особая роль разночтений, определяющих динамику развития главной лирической темы. Партия Совести, базирующаяся на выразительной семантике первого члена доминантной эхо-рифмы «ил - любил», т. е. мертвого, затягивающего подводного грунта, варьируется следующим образом:

8 Здесь и далее текст трагедии цитируется в переводе М. Л. Лозинского. 
«На дне она, где ил / И водоросли... / Спать в них / Ушла, — но сна и там нет!» «- Гамлет! // На дне она, где ил: // Ил!.. И последний венчик / Всплыл на приречных бревнах...»

«На дне она, где ил».

Как видим, в двух первых случаях ключевой, трижды повторяющийся стих «На дне она, где ил» сопровождается уточнением, детализацией и описанием обстоятельств гибели героини. В третьем случае остается чистая констатация. Налицо динамика затухания в преддверии окончательного вывода.

Примерно такую же картину видим в чередовании реплик оправдывающегося героя, у которого, в сущности, нет других доводов, кроме смягчающего его вину страстного любовного чувства к Офелии, которое он из тактических соображений глубоко скрывал от всех, в том числе и от нее. Но именно оно неотвратимо, как шагреневая кожа, съеживается и форсированной вопросительной интонацией, в конце концов, ставится под сомнение:

«— Но я ее любил, / Как сорок тысяч братьев / любить не могут!»

«- Но я ее любил, / Как сорок тысяч...»

«- Но я ее - / любил??»

Практически все реплики прерываются непререкаемым голосом Совести. Вначале, как уже отмечалось, оборванная строка заполняется на новой ступени нетерпеливо-экспрессивным обращением к собеседнику: «- Гамлет!», затем в той же активной позиции, выделенный энергичным логическим ударением оказывается окказиональный антоним к гиперболическому «множеству» братской любви: «- Меньше, / Все ж, чем один любовник». Финальная строка как будто завершена, в третий раз замыкая неразлучную рифмопару «ил - любил», но во-первых, она резко членится на две ступени, а во-вторых вопросительная интонация дезавуирует и без того замирающую энергию утверждения.

Экстраординарная роль знаков препинания и эквивалентных им приемов версификационной графики, не говоря уже о фирменных enjambements Цветаевой, в ее стихопоэтике общеизвестна. В рассматриваемом стихотворении они, дополняя и дублируя друг друга, ведут себя исключительно активно, значимо разрывая и без того короткие 3-стопные строки на еще более дробные, а потому в высшей степени экспрессивные доли, продуцируя многозначительные паузы внутри стихов и активизируя вдобавок интенсивную звукопись.

Так в первом шестистишии многоточие во 2-м стихе сигнализирует об асимметричной паузе вопреки второму стопоразделу («И во|дорос|ли... 
Спать в них...»). В 3-м стихе подобный эффект обеспечивает тире (с запятой), отбивающее концовку распятой анжамбеманом между 2-м и 3-м стихами фразы: «Спать в них / Ушла, — но сна и там нет!». На этот раз синтаксическая пауза совпадает со стопоразделом, зато активизируется следующий после тире противительный союз «но», коррелирующий с аналогичным зачином в лейтмотивном оправдании Гамлета «Но я ее любил». Наконец, в этом же ряду следует рассматривать графическое членение заключительного 6-го стиха, в котором тире играет амбивалентную роль собственно тире и знака, сигнализирующего о прямой речи, принадлежащей другому, в данном случае аллегорическому, лицу (Совести).

Благодаря перемещению в рифмованную концовку предыдущего стиха обращения «- Гамлет!» второе шестистишие открывается вполне нейтральной, на первый взгляд, констатацией: «На дне она, где ил:» с трудно объяснимым двоеточием перед межстиховой паузой. Однако многоточие после восклицательного знака разрубает следующий 2-й стих, оставляя в левой его части эхо односложного же финального слова предыдущей строки и узаконивая один из самых резких ритмических перебоев - форсированное ударение на первом (хореическом) слоге - в сочетании с ямбическим отягощением безударного односложного союза «И», вследствие чего хориямб превращается в ярко выраженный спондей «Ил!.. И». Многоточие в концовке 3-го стиха «Всплыл ${ }^{9}$ на приречных бревнах...» знаменует собой фигуру умолчания, паузу, приглашающую сопоставить следствие и причину, чтобы заключить: Офелия навсегда осталась «на дне <..>, где ил». Еще одно многоточие фиксирует оборванную фразу Гамлета «Как сорок тысяч...» и одновременно в очередной раз, меняя аспект высказывания, дает слово его совести: «Меньше, / Все ж, чем один любовник». Можно, впрочем, не сомневаться, убеждение, запечатленное в столь ригорично выраженной максиме, разделяет с ней сам автор.

Самая лаконичная часть стихотворения - его финальное двустишие, напоминающее коду онегинской строфы или более уместного в нашем случае шекспировского сонета. Оно состоит из рефренной посылки Совести «На дне она, где ил» и редуцировавшейся до одной строки реплики Гамлета: «- Но я ее - / любил??». Тире в завершение второй части заключительного стиха равносильно раздумчивому многоточию и действует в унисон с графи-

\footnotetext{
9 Глагол «Всплыл» попутно образует начальную рифму с открывающим предыдущую строку лейтмотивным существительным «Ил!..», вовлекаясь в общее, пронизывающее весь «Диалог» насквозь сомнамбулически-тавтологическое, сверхмногочленное рифмование: «ил — любил — ил — ил — всплыл — любил — ил - любил», где четырежды повторенное слово «ил» в устах Совести отзывается эхо-рифмой к все менее и менее убедительному оправданию Гамлета «любил».
} 
ческим переломом строки. Однако наибольшей экспрессивной функцией наделен сдвоенный вопросительный знак, завершающий диалог. Этот круто меняющий интонацию и смысловой итог всего стихотворения вопрос Гамлет задает себе самому!

Эмоциональное исступление, пассионарная одержимость idée fixe выражаются не только на рефренных повторах одних и тех же с небольшими вариациями словосочетаний, тавтологических рифм и освященных авторитетом шекспировского гения образов, но и идентичных звуков и слогов на основе аллитерации на «н»: «На дне она - в них - но - нет - но - не - на - дне она - на - приречных бревнах - но - любовник - на дне она HO».

В ритмическом отношении «Диалог Гамлета с совестью» также весьма примечателен: на фоне десяти полноударных ямбических трехстопников (ЯЯЯ) с весьма прихотливым чередованием женской и мужской каталектик (äBCaBCaDEaDEaa), только четыре стиха содержат в себе отклонения от метрического стандарта: 2-й, 8-й, 9-й и 12-й - все четыре женские:

$\begin{array}{ll}\text { И водоросли... Спать в них } & \text { ЯПЯ } \\ \text { Ил!.. И последний венчик } & \text { СЯЯ } \\ \text { Всплыл на приречных бревнах... } & \text { ХЯЯ } \\ \text { Все ж, чем один любовник. } & \text { СЯЯ }\end{array}$

Их ритмическая структура, далеко не унифицированная, как легко убедиться, гармонично взаимодействует с синтаксическим строем и образным содержанием соответствующих стихов. Первые два случая уже были рассмотрены выше. Переполненное согласными, в том числе сонорными «л», односложное слово «всплыл», открывая 9-й стих, синтаксически продолжающий 8-й, образует очевидный хореический ход в зачине ямбического стиха. Тем самым продуцируется весьма пластичный ритмический жест, аккомпанирующий образному жесту вспльтия. Правда, вовлеченность в общую цепь звуковых повторов предлога «на», расположенного на четной (ямбической) позиции, оставляет возможность его эксклюзивной акцентуации и, следовательно, трактовки первой стопы как спондея.

6.

Своеобразным отголоском «Диалога» воспринимается написанное двумя неделями позже, 18 июня 1923 г., стихотворение «Свиданье» («На назначенное свиданье...») имевшее первоначальный заголовок «Офелия». 
Захвативши - приду седая.

Ты его высоко назначил!

Буду годы идти - не дрогнул

Вкус Офелии к горькой руте!

Через горы идти - и стогны,

Через души идти - и руки.

Землю долго прожить! Трущоба -

Кровь! и каждая капля - заводь.

Но всегда стороной ручьевой

Лик Офелии в горьких травах.

Той, что, страсти хлебнув, лишь ила

Нахлебалась! - Снопом на щебень!

Я тебя высоко любила:

Я себя схоронила в небе!

На этот раз лирическая героиня остается самой собой, отправляясь «на назначенное свидание» с роковым шекспировским героем. Пространство и время в поэзии соотносимы, как сообщающиеся сосуды. Пожалуй, лучше всего эту парадоксальную закономерность уловил и выразил И. А. Бродский. Находясь в камере предварительного заключения перед судом, он вывел формулу тюрьмы, которая есть не что иное, как «недостаток пространства, возмещенный избытком времени» (Бродский, 1999: 24) ${ }^{10}$. Для лирической героини Цветаевой, как и в случае с ахматовской Дидоной, несколько сотен лет опоздания оборачиваются всего лишь «весной впридачу», однако путь ее во времени столь долог, земная дорога к любимому в пространстве столь протяженна, что на свиданье она приходит совсем «седая».

Любовная трагедия Офелии переживается лирической героиней и за нее, и за себя в глобальном, вселенском масштабе; она поистине всеобща и неизбывна: «Землю долго прожить! Трущоба - / Кровь! и каждая капля заводь. / Но всегда стороной ручьевой / Лик Офелии в горьких травах. // Той, что, страсти хлебнув, лишь ила / «Нахлебалась! - Снопом на щебень!» и как следствие — отчаянный финальный выкрик: «Я тебя высоко любила: / Я себя схоронила в небе!».

${ }^{10}$ Ср.: «Основное свойство пространства - изменчивость, согласная с известным афоризмом о реке, куда невозможно войти дважды. В этом смысле река изменчивее своего течения, которое постоянно, а пространство (по Бродскому) изменчивее времени, мыслимого скорее как вечность. Время почти теряет направленность; оно всегда длится и само по себе не знает перемен, поэтому любое путешествие во времени есть, в сущности, путешествие в пространстве» (Шайтанов, 2007: 391). 
Благодаря дважды употребленному эпитету «высоко́», выраженному не то наречием, не то категорией состояния, сначала по отношению к «назначенному свиданью», а потом к накалу возвышенной любовной страсти, вектор движения новоявленной Офелии к возлюбленному обозначается не в горизонтальном, а вертикальном направлении. При этом каламбурно синтезируются местоположение небесной могилы и нравственная оценка состоявшегося в конце концов свидания. Жертвенная любовь для нее - несомненно богоугодное дело.

Разумеется, четыре цветаевских текста, написанные по мотивам «Гамлета» в относительно короткий промежуток времени, не могут анализироваться изолированно друг от друга. Не имея конкретного общего заголовка и каких-либо явных структурных перекличек-скреп (например, жанровых, метрических или строфических доминант), они тем не менее образуют определенный крепко спаянный интертекст. Их роднит не только единый источник, не только хорошо знакомые нам образы, вписанные в хрестоматийный сюжет, но и характерные приметы свойственных обоим поэтам художественных миров и идиостилей. Таковы, в частности, детали хронотопа ручья, дна, ила, образное уподобление сна смерти, противопоставление смерти бессмертию, земли - небу, явное предпочтение вертикального движения устремленного к предмету своей страсти лирического субъекта горизонтальному («ввысь», к небесной могиле, со дна ручья), страстная экстатическая интонация и, наконец, сквозные звуковые повторы, главным образом, на базе аллитерирующих протяжных сонорных «н» и «л». Разночтения, однако, дают о себе знать в главном - в нравственной оценке перипетий любовной драмы Гамлета и Офелии, осмысленной в мировом, вневременном масштабе.

Итак, четыре рассмотренных нами стихотворения составляют неразрывное циклическое единство. Один из центральных персонажей шекспировского шедевра Офелия находит сочувственный отклик в душе отождествившей себя с ней лирической героини, предельно близкой биографической личности поэта. Трагедия ее принесенной в жертву любви приобретает универсальный — всеобщий и в то же время личностно ${ }^{11}$ переживаемый — ха-

${ }^{11}$ Стихотворение было написано в то время, когда М. И. Цветаева с мужем и дочерью жи-
ла в захолустном чешском городишке Мокропсы. Увлеченная творчеством, она вела ин-
тенсивную переписку с близкими ей по духу людьми, в частности, с Б. Л. Пастернаком и
молодым 20-летним критиком А. В. Бахрахом. Невстреча с первым в Германии и внезап-
ное, затянувшееся на месяц молчание второго, испугавшегося чрезмерной пылкости вы-
ражаемых ею вполне бескорыстных чувств, а также надвигающаяся страстная любовь к
К. Б. Родзевичу, все это, видимо, побудило ее вспомнить любовную историю датского 
рактер. Перед непреклонным судом совести именно «бессмертная» любовная страсть оказывается превыше сомнительных идейных химер («вздорной нежити») возомнившего себя спасителем чуть ли не всего человечества Гамлета: «Порвалась дней связующая нить./ И мне теперь ее соединить!». «Девственник» и «женоненавистник», он, окольным путем уподобившись Ипполиту, сам оказывается предателем как по отношению к матери, так и по отношению к любимой. Одну он не имел морального права осуждать за постигшую ее катастрофическую страсть (ведь даже Призрак отца молил его о пощаде и милосердии), другую - обрекать на безумие, настоящее, кстати сказать, а не притворное, как у него самого. Заметим, что приговор, продиктованный совестью, Гамлет произносит себе сам. Таким образом, гамлетовско-офелиевский цикл Цветаевой в целом можно назвать вдохновенным гимном всепоглощающей жертвенной женской любви, во все времена противостоящей внешне активному, действенному, но по сути своей бесплодному мужскому тщеславию.

\section{7.}

Обращаясь к шекспировскому шедевру, М. И. Цветаева, конечно, не могла не учитывать аналогичный опыт своих многочисленных предшественников: Н. А. Некрасова («Офелия», 1840), А. А. Фета (цикл «К Офелии», $<1842-1847>$ ), В. Я. Брюсова («Офелия», 1911), А. А. Блока («Я шел во тьме к заботам и веселью...», 2 августа 1898; «Есть в дикой роще, у оврага...», 8 ноября 1898; «Офелия в цветах, в уборе», 30 ноября 1898; «Мне снилась снова ты, в цветах, на шумной сцене...», 23 декабря 1898; две «Песни Офелии», 1902 и 1908; «Я - Га́млет: холодеет кровь...», 6 февраля 1914), А. А. Ахматовой (лирический диптих «Читая Гамлета»: 1. «У кладбища направо пылил пустырь...»; 2. «И как будто по ошибке...», 1909). Знаменательно, что подавляющее большинство поэтических фантазий на тему великой шекспировской трагедии связано не с главным его конфликтом - противостоянием принца-гуманиста окружающему его вывихнутому миру, а в основном с любовной драмой, причем с явным, преимущественным интересом к страдательному ее участнику — Офелии.

принца. Неслучайно параллельно она собирала материал для своей новой трагедии «Ариадна», завершенной в следующем 1924 г., в которой Тезей также отказывается от своей возлюбленной, что называется ради высших целей (Ариадну избрал сам Вакх). 
В пространном стихотворении Н. А. Некрасова образ Офелии всего лишь задан Шекспиром, но интерпретирован русским поэтом в соответствие с его по большей части еще романтическим представлением о судьбе обманувшейся в своих любовных упованиях девушки и весьма экстатически переживающей постигшее ее разочарование: «В наряде странность, беспорядок, / Глаза - две молнии во мгле, / Неуловимый отпечаток / Какой-то тайны на челе; / В лице то дерзость, то стыдливость, / Полупечальный, дикий взор, / В движеньях стройность и красивость - / Все чудно в ней!..». Подобно лермонтовскому Мцыри, она блуждает «по высям гор, / в долинах, рощах» и «...как зверь / Дичится» какого-то абстрактного «друга, из приязни / Ей отворяющего дверь». Не только Шекспиром (в речи Гертруды), но и Лермонтовым, а возможно и Пушкиным, навеяно сравнение ее с русалкой:

Порой на лодке в непогоду, Влетая в бунт морских зыбей, Обезоруживает воду Геройской дерзостью своей. На брег выходит; как русалка, Полощет волосы в волнах...

(Некрасов, 1981: 280; курсив наш. $-\Phi$. О.)

Постигшее ее безумие в поступках не изображается, а только с сожалением констатируется: «В ней сон безумья непробудный / Царит над чувством и умом. / Он все смешал в ней без различья, / Лишь дышат мыслию черты, / Как отблеск прежнего величья / Ее духовной красоты...» (там же: 280-281).

Столь отстраненное изображение шекспировской героини, как будто речь идет об исполняющей ее роль абстрактной актрисе, дальнейшего развития в русской поэзии не получило. Гораздо продуктивнее оказался пример А. А. Фета, довольно точно следующего за Шекспиром ${ }^{12}$, наполнившего образ Офелии лиризмом и отождествившего ее со своей реальной возлюбленной.

\section{***}

Образ Офелии стал одним из доминантных воплощений характера лирической героини А. А. Фета не только благодаря обаянию шекспировского

\footnotetext{
12 За исключением, может быть, стихотворения «Я болен, Офелия, милый мой друг...», в котором лирический герой обращается к Офелии с просьбой спеть ему о том, как носится ветер вокруг/ Его (? - О. Ф.) одинокой могилы» и про некую «Иву сестры Дездемоны» (Фет, 1959: 132).
} 
гения, но и по причинам чисто биографического порядка. Когда Фет в студенческие годы жил в доме Ап. А. Григорьева на Малой Полянке, оба молодых поэта были влюблены в некую Елизавету, крестную дочь кого-то из родителей Аполлона. Судя по поэме Фета «Студент» (<1884>) и воспоминаниям Григорьева «Офелия» (1846), она предпочла первого, но вышла замуж за кого-то третьего. Девушка мечтала об артистической карьере, вдохновлялась ролью Офелии, почему и получила соответствующее поэтическое имя. В ее судьбе, получается, не было ничего трагического; довольно и того, что она пробудила в молодых людях высокие творческие ассоциации с героиней признанного шедевра Шекспира. С другой стороны, это мимолетное увлечение аукнулось впоследствии настоящей драмой в жизни Фета. Пожертвовав любовью другой девушки, Марии Лазич, он вновь ощутил себя Гамлетом, на этот раз более чем всерьез, с по-настоящему трагическим исходом (возлюбленная погибла от неосторожно брошенной спички).

Так или иначе, в ранней лирике Фета, созданной между 1842 и 1847 г., образом Офелии было навеяно ни много, ни мало одиннадцать стихотворений: 1) «Не здесь ли ты легкою тенью...»; 2) «Сосна так темна, хоть и месяц...»; 3) «Как майский голубоокий...»; 4) «Сонет» («С тех пор, как бог в тебе осуществил...»); 5) «Стихом моим незвучным и упорным...»; 6) «Горный ключ» («С камня на камень висящий...»), 1842; 7) «Как ангел неба безмятежный...», 1843; 8) «Офелия гибла и пела...», 1846; 9) «Прости (Офелии)» («Прости, — я помню то мгновенье...»), <1846>; 10) «Как идет к вам чепчик новый...»; 11) «Я болен, Офелия, милый мой друг», 1847. Из них, однако, только четыре вошли в цикл под общим названием «К Офелии» (№№ $1,7,8,11)$.

Все они крепко связаны общей ангельской темой (окказиональными синонимами «безмятежному ангелу неба» выступают объединенные притяжательным местоимением лейтмотивные понятия «гения» ${ }^{13}$ и «друга»: «Мой гений, мой ангел, мой друг»), а также мотивом мистического общения лирического героя с уже переселившейся на небо душой возлюбленной: «Как ангел неба безмятежный, / В сияньи тихого огня / Ты помолись душою нежной / И за себя и за меня» (Фет, 1959: 133). Союз «как» в данном случае сигнализирует не о сравнении, а о замещении живого человека ангелом.

Лирический герой, пожалуй, не претендует здесь на тождество с Гамлетом, а скорее как поэт чувствует себя режиссером воображаемого спектакля. Судьбу покинувшей его, а потому вроде бы умершей возлюбленной он не столько реконструирует, сколько домысливает по сценарию, заданному

13 Здесь, конечно, ощутима интертекстуальная перекличка с хрестоматийным «гением чистой красоты» Жуковского-Пушкина. 
Шекспиром. Таким образом Офелия у него своя, не заемная, а ее шекспировская тезка, вместе с «сестрой Дездемоной» - всего лишь литературные персонажи, роли которых, перевоплотившись, она не сыграла, но могла бы сыграть.

Столь же основательно, с оглядкой на первоисточник декорируется и сцена для лиро-драматического представления. Понятно, что в «одинокой могиле», вокруг которой носится ветер в воображаемой песне Офелии, покоится ее отец, незадачливый шпион Полоний, понятно и то, почему понадобилось спеть еще и про зеленую иву, «про иву сестры Дездемоны». Все обманувшиеся в своих любовных чаяниях девушки и в прошлом, и в настоящем, и в будущем - сестры, а их печальную судьбу олицетворяет собой плакучая ива - традиционный символ горя и смерти.

Уже хорошо знакомый нам адресат, в котором воедино слились два жизненных прототипа лирической героини раннего А. А. Фета с образом возлюбленной Гамлета, запечатлен в подзаголовках двух стихотворений, написанных в 1842 и 1846 г.: «Сонет (Офелии)» («С тех пор, как бог в тебе осуществил...») и «Прости» («Офелии») («Прости, — я помню то мгновенье...»). В первом из них сопоставляется подсказанное свыше («осуществленное богом») «создание поэта» и необъяснимая страсть к изощренной сонетной форме. Высказываются три равно возможных предположения: быть может чувства, взволновавшие поэта, нашли отражение в тех же рифмах, которыми некогда вдохновлялся певец смуглой дамы; или сам сонет схож с возлюбленной тем, что обладать обоими непросто, или, наконец, тем, что побежденная трудность, «смиряясь», «становится милее» (Фет, 1959: 415). Странно лишь, что после прямой отсылки к Шекспиру, Фет не воспользовался так называемым «шекспировским» сонетом, а предпочел ему классическую французскую модель. Скорее всего, молодой поэт, возводя прообраз своей возлюбленной к «созданию поэта», имел в виду не только Шекспира, но и Пушкина, под обаянием сонетианы которого он долгое время находилcr $^{14}$.

В прощальном стихотворении «Прости», обращенном к той, первая встреча с которой была дарована провиденьем, а затем «Как птичка вешнею зарею, / Как ангел отроческих снов» унесла, как водится, с собою «безумную любовь» лирического героя. Он трогательно благодарит и «провиденье» и

14 В этом отношении особенно показательны такие сонеты А. А. Фета, как: «Владычица Сиона, пред тобою...»; «Мадонна» («Я не ропщу на трудный путь земной...»); «Сонет» (Офелии) («С тех пор, как бог в тебе осуществил...»), <1842>; и значительно позже «К Сикстинской Мадонне» («Вот сын ее, — он — тайна Иеговы — ...»), 1864 (?), в которых развиваются мотивы пушкинских сонетов «Суровый Дант» и «Мадона» (Федотов, 2011b: 171-181). 
свою подругу и навсегда прощается с ней. Помета «(Офелии)» чисто внешним, формальным образом отсылает к шекспировскому «Гамлету», потому что прощающийся с любимой персонаж больше напоминает не датского принца, а Онегина, произносящего в ларинском саду не столько «исповедь», сколько «проповедь».

На фоне трех задушевных обращений к умершей возлюбленной (№№ 1, 8, 10) выделяется как идейный эпицентр всего цикла исповедальное описание ее гибели: «Офелия гибла и пела...»:

Офелия гибла и пела,

И пела, сплетая венки;

С цветами, венками и песнью

На дно опускалась реки.

И многое с песнями канет

Мне в душу на темное дно,

И много мне чувства, и песен,

И слез, и мечтаний дано.

$(\text { Фет, 1959: 133) })^{15}$

Первое четверостишие этого стихотворения послужило эпиграфом для весьма оригинальной интерпретации образа Офелии В. Я. Брюсовым. Его Офелия «не сплетала венков», «не держала в руках свежих цветов», не пела таинственных песен и даже не стала утопленницей. При этом она явно не сходила с ума, хотя и пребывала в подозрительно «хмельном веселии», прежде чем «с диким хохотом» выбросилась из окна на мостовую, метафорически, кстати, названную «дном» ${ }^{16}:$ «Чего ж ты искала, давно желанного, / Блуждающим взором, внизу, на дне?». Нарицательное имя шекспировской героини она получила, скорее всего, пережив такую же любовную катастрофу.

\footnotetext{
${ }^{15}$ Подробнее см. также: Федотов, 2016.

${ }^{16} \mathrm{He}$ без влияния процитированных строчек А. А. Фета, в которых метафорически сливаются дно реки и дно души. Этой же цитатой, кстати сказать, воспользовался В. Ф. Ходасевич в письме к своей жене А. И. Ходасевич от 3 февраля 1922 г., сравнивая с шекспировской героиней парадоксальным образом самого себя: ““Офелия гибла и пела” — кто не гибнет, тот не поет. Прямо скажу: я пою и гибну. И ты, и никто уже не вернет меня. Я зову с собой - погибать. Бедную девочку Берберову я не погублю, потому что мне жаль ее. Я только обещал ей показать дорожку, на которой гибнут. Но, доведя до дорожки, дам ей бутерброд на обратный путь, а по дорожке дальше пойду один. Она-то просится на дорожку, этого им всем хочется, человечкам. А потом не выдерживают. И еще я ей сказал: “Ты не для орла, ты - для павлина". Все вы, деточки, для павлинов. Ну, конечно, и я не орел, а все-таки что-то вроде: когти кривые» (Ходасевич, 1997: 441).
} 
Внешним образом лирический субъект не принимает на себя вину за ее гибель, но рассказывает о ней не совсем вчуже, обращаясь к героине интимным местоимением 2-го лица «ты», «тебя». А детальные подробности происшествия, которые мог запечатлеть лишь очевидец, косвенно свидетельствуют о его если не активном участии в разыгравшейся трагедии, то во всяком случае о присутствии в неблаговидной роли пассивного соглядатая. Как тут не вспомнить о гибели шекспировской героини в красочном пересказе королевы Гертруды:

«Над ручьем наискось растет ива, которая отражает свои листья в зеркальном потоке. Туда пришла она с причудливыми гирляндами из листков, крапивы, маргариток и тех длинных пурпурных цветов, которым откровенные на язык пастухи дают грубое название, а наши холодные девушки называют пальцами мертвецов. Когда она взбиралась на иву, чтобы повесить на свисающие ветви сплетенные ею венки из цветов и трав, завистливый сучок подломился и вместе со своими трофеями из цветов она упала в плачущий ручей. Широко раскинулась ее одежда и некоторое время держала ее на воде, как русалку, и в это время она пела отрывки старых песен, как человек, не сознающий своей беды, или как существо, рожденное в водяной стихии и свыкшееся с ней. Но это могло продолжаться недолго, пока ее одежда не отяжелела от воды и не потащила несчастную от мелодичной песни к тенистой смерти» («Гамлет». IV, 7. Прозаический перевод М. М. Морозова: Морозов, 1954).

В комментариях к своему переводу «Трагедии принца Датского» (Шекспир, 2003b) А. Ю. Чернов, обосновывая концептуальный пересмотр образа Горацио, допускает, что именно он, получивший от короля наказ присмотреть за несчастной девушкой, мог помочь ей уйти из жизни или, по крайней мере, не помочь спастись, ведь это его отчет пересказывает Гертруда!

Как бы то ни было, В. Я. Брюсов вспоминает хрестоматийный образ в связи со своей лирической героиней, ассоциативно связывая его с перипетиями собственных бурных романов и, следовательно, с некоторыми претензиями на сходство себя самого с самым интеллектуальным и творчески креативным шекспировским героем.

Другое брюсовское стихотворение, порожденное гамлетовской темой, — «Закатный ветер» (1916) - парадоксальным образом обнажает точку зрения третьего персонажа, естественно, не третьего лишнего, а брата Офелии - Лаэрта: 
Веет древний ветр

В ветках вешних верб,

Сучья гнутся, ломятся.

Ветр, будь милосерд!

Ветви взвиты вверх,

Стоном их кто тронется?

Час на краски ще $р$ :

В небе - алый герб,

Весь закат - в веселии.

Ветр, будь милосе $p$ !

Я, как брат Лаэрm,

Плачу об Офелии.

Бледен лунный серn.

Там - тоска, ущерб;

Здесь - все светом залито.

Ветр, будь милосерд!

Кто во прах поверг,

Близ могилы, Гамлета?

Вздрогнет каждый нерв...

И из тайных недр

Память кажет облики...

Ветр, будь милосерд!

Верба, словно кедр,

Шлет на стоны отклики.

(Брюсов, 1973b: 282-283;

курсив наш. - $О . \Phi$.)

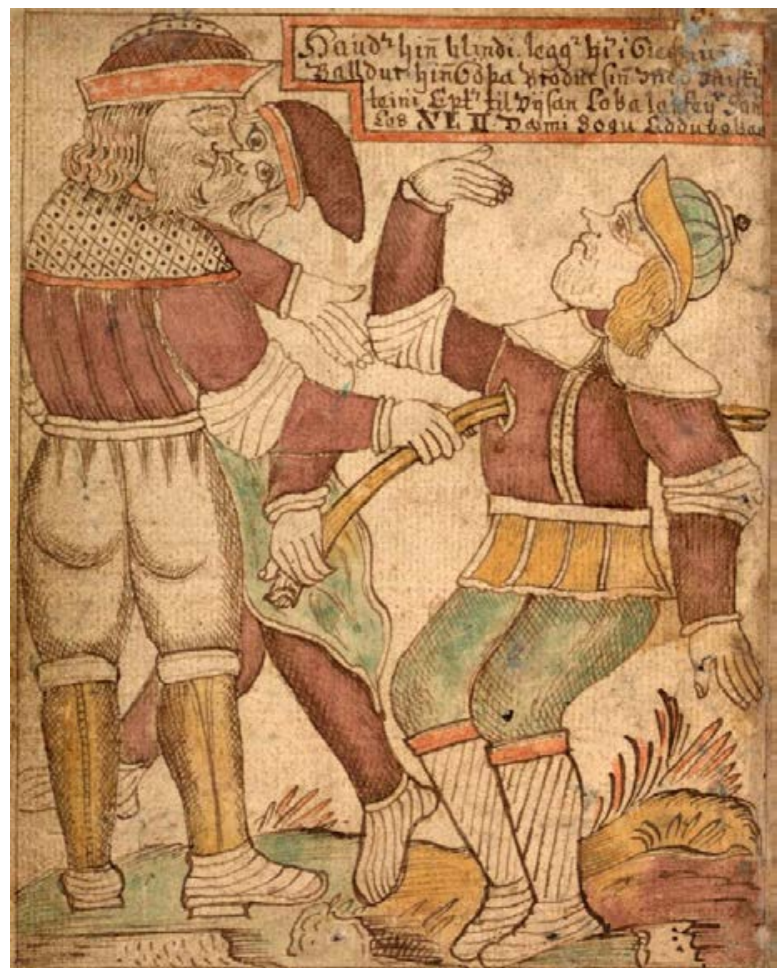


Конечно, этот голос существенно отличается от узнаваемых голосов обоих участников любовной драмы. Об Офелии плачет, видимо, не сам Лаэрт, а вообразивший себя им лирический герой. Почему он, вернее, стоящий за ним поэт, избрал в качестве своего заместителя, прямо скажем, не самого достойного шекспировского героя, осуществляющего кровную месть не по гуманистическим, а средневековым понятиям? Мало того, что он, поддавшись на уговоры Клавдия, согласился участвовать в подлом поединке против заведомо безоружного принца, он еще подстраховал себя ядом, чтобы убить наверняка. Ответ на этот вопрос, наверное, все-таки кроется в психологии В. Я. Брюсова, который сознательно искал, находил и культивировал в себе властный, жесткий, демонический характер. Вряд ли он шутил, когда говорил, что старается «остаться похожим на свой портрет, сделанный Врубелем» (Ашукин, 1929: 8, 206) ${ }^{17}$.

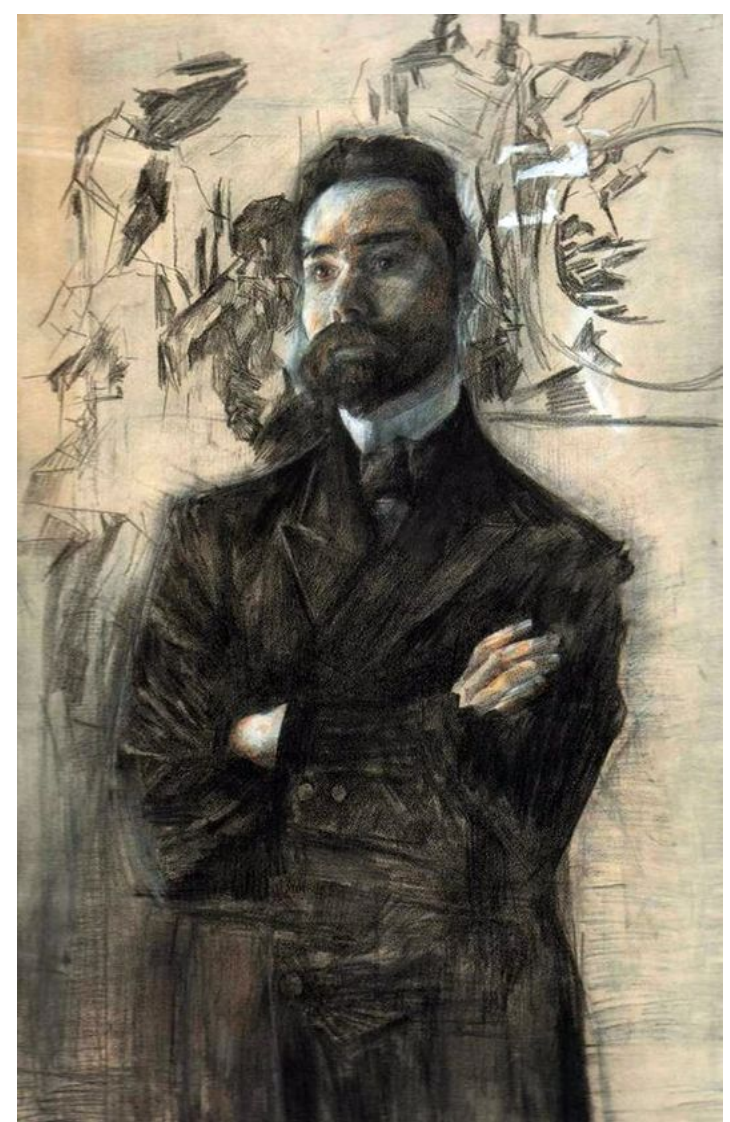

Можно также предположить, что в какой-то мере этот выбор был предопределен историей несостоявшейся дуэли с А. Белым, которого Вяч. Иванов уподобил скандинавскому мифологическому персонажу светлому богу Баль-

\footnotetext{
17 Не менее выразительна характеристика, данная В.Я. Брюсову проницательной Н. Я. Мандельштам: «Какому богу служил он, самоутверждаясь в своем роскошном вождизме и призывая грядущих гуннов? Не забыть: Брюсов еще изрек, что поэзия ни более ни менее как откровение» (Мандельштам, 1999: 49-50).
} 
д(е)ру, сыну Одина и Фригг ${ }^{18}$. Бальдра мучили зловещие сны, в которых разные предметы и явления природы угрожали ему смертью. Встревоженная мать взяла со всех вещей клятву, что они не будут вредить ее сыну, но забыла попросить об этом росток омелы (ольхи). Когда боги развлекались, бросая в неуязвимого Бальдра всякие предметы, один из них - злокозненный Локи, вооружив копьем, изготовленным из омелы, слепого бога Хаду, направил его руку в цель так, что копье сразило Бальдра насмерть. Этот сюжет был использован И. А. Буниным в 1904 г. в стихотворении «Бальдер» («Хаду слепец, он жалок. Мрак глубокий...»), а также самим В. Я. Брюсовым, написавшим и отправившим своему сопернику красноречивое стихотворное послание «Бальдеру Локи» (ноябрь 1904 г.), в котором именем светоносного скандинавского бога он называет Белого («Светлый Бальдер! мне навстречу / Ты, как солнце, взносишь лик»), а сам представляется исчадием мрака и зла Локи («Пусть в пещере яд змеиный / Жжет лицо мне, — я в бреду / Буду петь с моей Сигиной: / Бальдер! Бальдер! ты в аду!» (Брюсов, 1973а: 388-389) ${ }^{19}$.

О том, что Брюсов сознательно выбрал для себя маску аморального персонажа, готового на все, только бы «повергнуть во прах» своего недруга, косвенным образом свидетельствует и его оппонент: «...когда В. Я. воскликнул с совершенно искренним пафосом: “Что же, Борис Николаевич, ведь в Апокалипсисе сказано, что гад будет повержен в смерть. Итак: вы против гада, против слабейшего? Мне — жаль гада, бедный гад, я с гадом!"» (Белый, 1922: 95).

После того, как Белый отправил Брюсову жесткий парирующий ответ - стихотворение «Старинному врагу», с парадоксальным посвящением «В знак любви и уважения», тот признал свое поражение, откликнувшись второй, примирительной, версией «Бальтера» - «Бальтер II», с не менее эксцентричным эпиграфом из 3. Н. Гиппиус: «Тебя приветствую, мое поражение!»» 20

Как видим, многие мотивы здесь отчетливо перекликаются как с сюжетом «Гамлета», так и с его трактовкой в «Закатном ветре». Благодаря интер-

\footnotetext{
18 «Благодарю силы, которые призываю на тебя, за то, что преступление совершено тобою только в мире возможного. Ибо ты хотел убить Бальдера. < ..> Исполни мое желание: помирись с Бальдером сполна и братски, ибо ведь и ты, себя не узнающий, - светлый бог» (Литературное наследство ..., 1976: 473).

${ }^{19}$ Согласно Снорри, за это злодеяние боги приковали Локи к скале до конца мира, а над его лицом повесили ядовитую змею, яд которой приносил ему мучения. Правда, его верная жена Сигури (Сигюна), облегчая страдания мужа, держала над его головой чашу, однако время от времени чаша переполнялась и яд нужно было сливать, в эти промежутки капли попадали ему на темя, отчего великан содрогался, вызывая землетрясение.

${ }^{20}$ Перипетии этой фантастической и примечательной для нашей темы любовной истории во всех подробностях изложены в монографии: Лавров, Гречишкин, 2004: 6-62.
} 
текстуальным перекличкам дополнительную мотивировку получают эпитет «древний» по отношению, казалось бы, к совершенно конкретному ветру, противоборство мрака и света, неба и земли и, прежде всего, объединяющий Локи, Лаэрта и лирического героя ${ }^{21}$ Брюсова мотив яда.

Воображаемый монолог если не Лаэрта, то исполняющего эту незавидную роль лирического героя Брюсова отмечен удивительно нервной, изломанной ритмикой и соответствующей ей фоникой. Стихотворение написано малоупотребительным 3-стопным хореем с прихотливым чередованием мужских и дактилических рифм, исключающих акаталектическое слияние соседних стихов, которые, в результате, звучат не просто отрывисто, а поистине исступленно, почти с истерическим надрывом: «Ветр — верб - ломятся милосерд - вверх - тронется - щедр - герб - в веселии - милосерд Лаэрт - Офелии - серп - ущерб - залито - милосерд - поверг - Гамлета — нерв - недр - облики - милосерд — кедр - отклики».

aaB'a aaB'aaC'a aaC'aaD'aa'aaE'a aaE'

Все мужские рифмы, по сути дела, впрочем, ассонансы, сугубо закрыты, да не одним согласным, а двумя, с непременным характерным «надрывным» «р». С левой стороны с ними контрастно взаимодействуют анафорические и медиальные повторы «ве - «в вет - ве...» и т. д., призванные усилить пластический ряд звуковым, а именно - веяньем и завыванием ветра и взмывания вверх ветвей, не удержавших от самоубийственного шага Офелию. В конце концов к действующим лицам шекспировской трагедии - людям - присоединяются символические явления природы: ветр (в характерной архаической огласовке), ветки вешних верб, щедрый на краски алый герб заката, бледный лунный серп и заочно, через сравнение откликающийся на стоны ветвей вербы кедр. Четырежды тираду пронизывает рефренный стих «Ветр, будь милосерд!», осложненный на первой стопе спондеем, который в сочетании с пиррихием утяжеляет и без того немилосердную - употребим здесь любимое словечко И. А. Бродского - дикциюю ${ }^{22}$.

Мольба о милосердии, обращенная к ветру — идейный лейтмотив стихотворения, 24 стиха которого отчетливо делятся на четыре 6-стишия. В первом из них «древний ветр» заламывает «ветки вешних верб», из-за чего они издают стоны, которые никого не трогают. Во втором шестистишии щедрый

${ }^{21}$ И без того вообще не склонный подчеркивать «разность между Онегиным и мной», в нашем случае, между своим лирическим героем и собой, Брюсов меньше всего был озабочен этой проблемой в откровенно «жизнетворческих» поэтических разборках с А. Белым.

22 Заметим, что при атонировании первого слога 3-стопный хорей преображается в 2-стопный анапест. 
на краски вечерний час обозначен колоритным гербом заката, соединяющим небо с землей, с которым у лирического героя ассоциируется неуместное «веселие», поскольку он в это время, вообразив себя Лаэртом, оплакивает свою сестру Офелию. Третье шестистишие переносит нас еще выше, к бледному лунному серпу, обозначающему своим ущербом тоску и скорбь, по контрасту с залитой светом землей. Лирический герой, похоже, проклинает себя, что не поверг во прах на кладбище, у могилы сестры виновника ее гибели Гамлета.

Надо ли говорить о том, что брюсовская верба родственна шекспировской иве и, во всяком случае, тождественна ей по символике. У Брюсова, впрочем, это тождество осложняется сравнением вербы с кедром, который в христианстве ассоциируется с образом Христа и символизирует величие, достоинство и красоту.

\section{$* * *$}

Еще ранее пленительный образ Офелии в том же регистре, но гораздо активнее, многоаспектнее и шире был использован в любовной лирике А. А. Блока. 1 августа 1898 г. в Боблове, усадьбе Д. И. Менделеева, состоялся достопамятный любительский спектакль. Ставили «Гамлета» (разумеется, не всю трагедию, а лишь избранные сцены). Главные роли играли совсем еще юные в ту пору и уже влюбленные в друг друга Александр Блок и Любовь Менделеева. Артистические ощущения молодых людей, преобразившихся в своих персонажей, так глубоко поразили обоих, что творческим отголоском этого событии стал целый цикл из семи стихотворений, написанный Блоком между августом 1898 и февралем 1914 г., и детальное его описание Любовью Дмитриевной в ее книге воспоминаний «И быль и небылицы о Блоке и о себе», появившейся гораздо позже, в 1929 г.: «Этот, может быть, десятиминутный разговор и был нашим “романом” первых лет встречи, поверх “актера”, поверх вымуштрованной “барышни”, в стране черных плащей, шпаг и беретов, в стране безумной Офелии, склоненной над потоком, где ей суждено погибнуть.

Этот разговор и остался для меня реальной связью с Блоком, когда мы встречались потом в городе - уже совсем в плане “барышни” и “студента”. Когда еще позднее - мы стали отдаляться, когда я стала опять от Блока отчуждаться, считая унизительной свою влюбленность в “холодного фата”, я все же говорила себе: “Но ведь было же”...

Был этот разговор и возвращение после него домой. От “театра” сенного сарая - до дома вниз под горку сквозь совсем молодой березничек, еле в рост человека. Августовская ночь черна в Московской губернии и 
“звезды были крупными необычно”. Как-то так вышло, что еще в костюмах (переодевались дома) мы ушли с Блоком вдвоем в кутерьме после спектакля и очутились вдвоем Офелией и Гамлетом в этой звездной ночи. Мы были еще в мире того разговора и было не страшно, когда прямо перед нами в широком небосводе медленно прочертил путь большой, сияющий голубизной метеор. “И вдруг звезда полночная упала”...

Перед природой, перед ее жизнью и участием в судьбах мы с Блоком, как оказалось потом, дышали одним дыханием. Эта голубая “звезда полночная” сказала все, что не было сказано. Пускай “ответ немел”, - “дитя Офелия” и не умела сказать ничего о том, что просияло мгновенно и перед взором и в сердцах.

Даже руки наши не встретились и смотрели мы прямо перед собой. И было нам шестнадцать и семнадцать лет» (цит. по: Александр Блок ... , 1980: 144).

Первое стихотворение А. А. Блока «гамлетовского» цикла «Я шел во тьме к заботам и веселью...» появилось буквально на следующий день, 2 августа 1898 г. Эпиграфом исполнитель заглавной роли выбрал слова Лаэрта, произнесенные им в 5-й сцене 4-го акта: «Тоску и грусть, страданья, самый ад / Все в красоту она преобразила» (в пер. А. И. Кронеберга). Создается впечатление, что слова стихотворения произносит актер, еще не вышедший из роли. Голос его взволнован, а потому выбранные слова недостаточно точны; нет-нет и дают о себе знать расхожие романтические штампы, алогизмы, неоправданные архаизмы и необязательные эпитеты (отчасти в стилистике переводчика пьесы):

\footnotetext{
Я шел во тьме к заботам и веселью, Вверху сверкал незримый мир духо́в. За думой вслед лилися трель за трелью Напевы звонкие пернатых соловьев. И вдруг звезда полночная упала, И ум опять ужалила змея... Я шел во тьме, и эхо повторяло: «Зачем дитя Офелия моя?»
}

Не слишком внятную фразу в заключительном стихе, повторяемую эхом, видимо, следует понимать не как обращение Гамлета к любимой в подтверждение догадки А. Ю. Чернова о тайной беременности Офелии, а как риторический вопрос к самому себе: «Зачем она наивна, как дитя?». В наивно-

\footnotetext{
23 Здесь и далее стихи А. А. Блока цитируется с указанием в круглых скобках тома и через запятую страниц по изданию: Блок, 1980.
} 
сти, кстати, упрекает свою дочь Полоний в 3-й сцене 1-го акта: “Affection, pooh you speak like a green girl / Unsifted in such perilous circumstance...” [«Ты говоришь, как малое дитя, / Опасности такой не постигая...»], хотя тут же предлагает ей воспользоваться маской наивной доверчивой девочки, но уже в тактических целях: "Marry, I will teach you think yourself a baby..." [«Я научу тебя, как прикинуться ребенком...» $\left.{ }^{24}\right]$. Офелия — «дитя невинное» и в глазах ее брата Лаэрта, когда в 5-й сцене 4-го акта он видит ее, обезумевшую, оплакивающую неадекватным пением смерть отца. Если допустить, что «Гамлет» на Бобловской сцене шел, судя по эпиграфу, в переводе А. И. Кронеберга, А. А. Блок наверняка чутко уловил эхо сравнения юной девушки с ребенком: «О роза майская! Офелия! Сестра! / Дитя невинное! О боже мой! / Неужли ум девицы молодой / Не крепче жизни старика седого?».

В своей книге «Гамаюн. Жизнь Александра Блока» А. Н. Орлов приводит первоначальный, более пространный вариант этого стихотворения под названием «Воспоминание о "Гамлете" 1 августа в Боблове»", с посвящением Л. Д. М., в котором между двумя катренами канонического текста значились еще два катрена:
«Зачем дитя Ты?» - мысли повторяли...
«Зачем дитя?» — мне вторил соловей...
Когда в безмолвной, мрачной, темной зале
Предстала тень Офелии моей.
И, бедный Гамлет, я был очарован,
Я ждал желанный сладостный ответ...
Ответ немел... и я, в душе взволнован,
Спросил: «Офелия, честна ты или нет!?!?..»

Понятно, почему эта биографическая конкретика была впоследствии изъята, но совсем не гамлетовский вопрос «Зачем дитя...?», пусть и в несколько преображенном виде, все же остался.

Через три месяца родилось еще одно стихотворение Блока на ту же тему — «Есть в дикой роще, у оврага...», 3 ноября 1898 г. (24 декабря 1914 г.). Поэтическое воображение переносит лирического героя к месту роковой гибели Офелии, к тому самому «зеленому холму», рядом с которым в вечной тени протекает ручей, поглотивший героиню трагедии. Размышляя над мучи-

\footnotetext{
${ }^{24}$ А. Ю. Чернов переводит этот пассаж несколько иначе: «А ты подумай и предстань пред ним / В обличии невинного младенца...».

25 Этот вариант сохранился, видимо, у Л. Д. Блок и был обнародован ею в упомянутой книге воспоминаний. Его же не вполне правомерно использует для своего анализа Н. О. Пашкина (Пашкина, 2012).
} 
тельными вопросами: зачем не вянут здешние цветы и зачем вообще не иссяк сам источник, он отвечает, можно сказать, за Гамлета и за себя самого:

Там, там, глубоко, под корнями

Лежат страдания мои,

Питая вечными слезами,

Офелия, цветы твои!

Своеобразным продолжением этого стихотворения, с почти дословным подхватом финальной строки, можно считать уже более отстраненный его вариант — «Офелия в цветах, в уборе...», появившийся 30 ноября 1898 г. и, видимо, также продолженный 24 декабря 1914 г.:

Офелия в цветах, в уборе

Из майских роз и нимф речных

В кудрях, с безумием во взоре,

Внимала звукам дум своих.

Я видел: ива молодая

Томилась, в озеро клонясь,

А девушка, венки сплетая,

Все пела, плача и смеясь.

Я видел принца над потоком,

В его глазах была печаль.

В оцепенении глубоком

Он наблюдал речную сталь.

А мимо тихо проплывало

Под ветками плакучих ив

Ее девичье покрывало

В сплетеньи майских роз и нимф.

(I, 57-58)

На этот раз лирический субъект выходит из роли и излагает сюжетные перипетии шекспировской трагедии (как литературного произведения или театрального спектакля) если не от себя, то от лица некоего стороннего наблюдателя, может быть, даже того же Горацио, посланного Клавдием «следить за ней позорче». Лишь в таком случае можно понять, почему он наблюдает не только за безумной возлюбленной принца и слышит ее предсмертную песню, но и за Гамлета, склонившегося над потоком очевидным образом после того, как Офелия уже утонула, иначе ее девичье покрывало и венок из «майских роз и нимф» не проплывали бы мимо. 
Нимфами (нимфеями), кстати, именовались кувшинки. Такое название они получили благодаря тому, что, согласно мифологической версии, некогда одна прекрасная нимфа, увидев Геракла, влюбилась в него и, будучи не в силах погрузиться на дно, превратилась в цветок. По народным же поверьям, в цветах кувшинок жили русалки (нимфы). Так что Гамлет в финале своего центрального монолога, назвав Офелию «нимфой», невольно напророчил ей гибель в воде.

Как видим, А. А. Блок существенно сократил количество символических цветов, составлявших венок Офелии. Кроме кувшинок он упоминает «майские розы». Роза, как известно, обладает поистине безграничной символикой, олицетворяя собой практически все, что угодно: красоту, совершенство, изящество, радость, любовь, удовольствие, хвалу, славу, пышность, блаженство, аромат, пламенность, гордость, мудрость, молитву, медитацию, тайну, таинство, тишину. Поэтому в нашем случае важно обратить внимание на эпитет «майские», намекающий скорее всего на древнеримские «розалии» - праздник, связанный с культом мертвых, отмечаемый между 11 мая и 15 июля. Этот обычай соблюдается в Италии до сих пор в так называемое Троицыно (Розовое) воскресенье (domenica rosata). С другой стороны, возможна ассоциативная связь со средневековым культом «майского дерева» (чаще всего розового куста, шиповника), вокруг которого танцевали девушки, славящие любовь, у истоков одного из ведущих жанров рыцарской лирики - баллады (Федотов, 2011b: 81-82 ${ }^{26}$. Не забудем также, что «розой мая» (“O rose of Мау”) именует свою лишившуюся рассудка сестру Лаэрт в 5-й сцене 4 акта.

Нельзя обойти вниманием и уже знакомый нам мотив ивы, дважды упомянутой поэтом во 2-м и 4-м катренах, сначала с эпитетом «молодая», а затем применительно, видимо, к целой роще - «плакучих ив». Не исключено, что вдохновляющим примером для Блока в этом отношении могло оказаться стихотворение Фета «Я болен, Офелия, милый мой друг!..» $(<1847>)$, в котором, как уже отмечалось, ива осеняет собой и одинокую могилу Полония, и место гибели Офелии, и дурные предчувствия ее литературной «сестры Дездемоны».

В конце того же 1898 г., 23 декабря, Блок пишет еще одно стихотворение, посвященное памятному спектаклю, — «Мне снилась снова ты, в цветах, на шумной сцене...».

26 Цветы Офелии, во всем их многообразии, подробно откомментированы А. Н. Горбуновым (Горбунов, 1985). 
Свой артистический триумф на пару с исполнительницей другой главной роли лирический герой видит во сне ${ }^{27}$. Возлюбленная партнерша предстает в его возбужденном восприятии подчеркнуто амбивалентно: «Безумная, как страсть» и «спокойная, как сон». Но почему он чувствует себя «повергнутым»? Ответить на этот вопрос однозначно вряд ли возможно: либо речь идет о некогда разыгранной роли Гамлета, жертвы коварства Клавдия и Лаэрта, или, что вероятнее, о нем самом, признавшем свое поражение в любовных раздорах и преклонившем колени перед любимой в знак примирения: «И думал: “Счастье там, я снова покорен!” (I, 61). Но ощущения полной гармонии нет: новоявленная Офелия смотрит на своего Гамлета не так, как бы ему хотелось: подчеркнуто холодно, «без счастья, без любви». В контраст происходящему вся сцена завалена цветами, розами, которыми забрасывали артистов благодарные зрители и с которыми «лились, лились <...> мечты», заметим, не артиста, а «бедного поэта».

Концовка стихотворения явно не удалась. С одной стороны, никак не мотивировано возвращение к уже отшумевшему действию разыгранной трагедии, с другой - не слишком содержательным выглядит параллелизм четных строк в сопровождении неубедительной бедной рифмы и неуместно комической детали (цветы буквально заваливают лирического героя и оказываются у него даже «на голове»); наконец, не вполне адекватно в образной системе катрена воспринимается «благоуханье», пусть и осыпанной цветами, но все-таки умершей Офелии:

Ты умерла, вся в розовом сияньи,

С цветами на груди, с цветами на кудрях,

А я стоял в твоем благоуханьи,

С цветами на груди, на голове, в руках...

Как полагает автор статьи «Интерпретация образов Гамлета и Офелии в русской поэзии “серебряного века"» О. Ю. Казимирчук, «осмысление шекспировского "Гамлета" как театрального действа заметно усложняет субъектную структуру стихотворения», вследствие чего «трагическую тональность этому стихотворению придает именно сюжет о неразделенной любви героя-

\footnotetext{
${ }^{27}$ Изображаемый спектакль во сне в известной мере аналогичен театру в театре, представленный Шекспиром во 2-й сцене 3-го акта «Гамлета», которую традиционно называют «Мышеловкой», и сродни образно-философской метафоре сна-смерти, столь концептуально прозвучавшей в монологе заглавного героя: “...to die, to sleep / No more, and by a sleep to say we end / <...> to die to sleep, / To sleep, perchance to dream, ay there's the rub, / For in that sleep of death what dream my come..." [«...Умереть, уснуть / И все. И сном сказать: конец <.. > / .. Смерть и сон... / Во сне возможны сны... Да, вот и клин: / Что за виденья в мертвый сон придут...»] (пер. И. В. Пешкова).
} 
поэта, тогда как шекспировский мотив смерти Офелии благодаря контексту театрального действа утрачивает свою трагическую окраску (хотя, в то же время, опять использованы все мотивы, сопутствующие образу Офелии: страсть, безумие, цветы, смерть)» (Казимирчук, 2005). Поэтому, получается, благоухание исходит не от Офелии, а от исполнительницы ее роли, и лирического героя волнует не столько смерть возлюбленной датского принца, сколько холодность во взгляде актрисы, исполнившей ее роль. В таком случае приходится признать неоправданно двусмысленным утверждение «Ты умерла».

Еще одним отголоском сцен, сыгранных на любительских подмостках в Боблове, стало стихотворение 1900 г. «Прошедших дней немеркнувшим сияньем...», в котором, отчасти нарушая рифмовку, цитируются два стиха из шекспировской трагедии в переводе того же А. И. Кронеберга. А. А. Блок переставляет их, меняя местами, и выделяет курсивом:

Прошедших дней немеркнущим сияньем
Душа, как прежде, вся озарена.
Но осень ранняя, задумчиво грустна,
Овеяла меня тоскующим дыханьем.
Близка разлука. Ночь темна.
А все звучит вдали, как в те младые дни.
Мои грехи в твоих святых молитвах,
Офелия, о нимфа, помяни.
И полнится душа тревожно и напрасно
Воспоминаньем дальным и прекрасным.

28 мая 1900 г.

(I, 100-101)

В словах Гамлета, с горечью произнесенных им в финале своего монолога «Быть или не быть», лирический герой пытается обрести волевой импульс для того, чтобы с достоинством перенести вынужденную, как ему кажется, разлуку, ведь помолиться за него Гамлет просит Офелию после того, как твердо решил порвать с ней, и перед тем, как посоветовать ей стать монахиней.

В 1899 и 1902 (1904) г. «гамлетовский» цикл Блока продолжили две «Песни Офелии» («Разлучаясь с девой милой...» и «Он вчера нашептал мне много...»). В обеих песнях Офелия остается наедине с собой или, вернее, со своим безумием. Сомнительны поэтому попытки Н. О. Пашкиной рассматривать их как очередную стадию развития любовной истории персонифицированных лирических героев - неизбежного разочарования, которое «ведет к трансформации образа Гамлета», как бы взрослеющего на наших глазах: «В начале Гамлет — юноша, пылко влюбленный, жаждущий ответа и взаим- 
ности Офелии. Далее это уже рыцарь, верный служитель своей Дамы. На следующем этапе - Гамлет-воин; но пока неизвестно, в какой именно край и с какой целью он отправляется. В последнем стихотворении Гамлет приобретает таинственный облик: лицо его “страшное”, он молчалив - не говорит, а только шепчет и тоже “страшное”. В словах Офелии постоянно подчеркивается: каким он был еще недавно и каким предстал перед ней в момент их последней встречи — “вчера”. Думается, что здесь отразился переломный момент в судьбе героя и далее следует ожидать появления его нового облика» (Пашкина, 2012: 220).

Напротив, О. Ю. Казимирчук усматривает отличия первой блоковской «Песни Офелии» от материала первоисточника в том, что «Блок игнорирует значимый для Шекспира мотив безумия... к тому же поэт существенно трансформирует содержание песни. В шекспировской песне Офелии преобладают мотивы, связанные со смертью отца, а блоковская Офелия вспоминает о “друге”, о “милом воине”, здесь тема смерти связана с образом принца, хотя его имя так и не названо» (Казимирчук, 2005). Здесь, надо полагать, Офелия поет не от себя, а вспоминает одну из подходящих по тематике народных песенок, которые в эпоху крестовых походов были весьма популярны. И Блок это прекрасно понимал.

Таким образом, обе «Песни Офелии», в интерпретации Блока, представляют собой всего-навсего имитацию песен безумной героини, лишившейся рассудка по-настоящему, а не притворно, как Гамлет. Поскольку действие шекспировской пьесы развертывается в Дании, а не в Англии, где по словам веселого могильщика, «рехнувшегося» Гамлета несомненно примут за своего, ибо «там все такие полоумные», персонажи со здоровой психикой предполагают в речах и песнях Офелии некий скрытый смысл. Казалось бы, бессвязные слова сестры «Вам надо петь: “в могилу, в могилу, зовите в могилу его!” А как идет этот напев к шуму колеса на самопрялке! Ведь это управитель соблазнил дочь своего господина» Лаэрт воспринимает и комментирует, отдавая должное скрытым в них намекам: «Этот вздор значительнее смысла». А чуть позже символическую трактовку ею цветов: «Вот незабудки - это на память: не забывай меня, милый друг! А вот повилика — она означает верность» он также пытается совместить со здравым смыслом: «Поучение среди безумства; помянуты любовь и верность» (пер. А. И. Кронеберга). Примерно ту же работу проделывают, однако, и исследователи, и переводчики. При этом их выводы оказываются не менее субъективны и противоречивы, чем истолкования авгуров или диагнозы психиатров. Не случайно, в переводах прежде всего песен Офелии больше всего разночтений. Любовь Дмитриевна, кстати, обмолвилась как-то о том, что они с Блоком изучали 
разные их переводы, среди которых он однажды прочитал ей свое стихотворение (Блок, 1997: 293), т. е. причислил его тем самым именно к этой разновидности творчества.

Традиционно образ Офелии трактуется преимущественно с мужской точки зрения: «Офелия погибла для Гамлета не оттого, что она безвольная дочь старого шута, не оттого даже, что она живность, которую тот хотел бы продать подороже, а оттого, что брак вообще не может быть прекрасен и что благородная красота девушки должна умирать одинокая, под черным вуалем и при тающем воске церковной свечи» (Анненский, 1979: 166). И только поэты, особенно поэтессы, стремились трактовать трагедию героини не извне, а изнутри, через ее восприятие. А ей было от чего лишиться рассудка. Она понесла три утраты подряд: сумасшествие, пусть и мнимое, Гамлета, его внезапно и грубо оборванную любовь, а также в довершение свалившихся на нее бед гибель отца от руки любимого. В результате все перемешалось в ее бедной голове. Все пережитые ею несчастья она сублимирует в традиционные фольклорные и литературные сюжеты о воине, отправившемся завоевывать чужие края и сгинувшем там, о девушке, потерявшей невинность до брака и отвергнутой соблазнителем, и, наконец, о молодом веселом Робине, легшем спать в могильную кровать; его белая, как снег, борода и желтая, как лен, голова, причудливо совмещают приметы Полония и Гамлета.

А. А. Блок в обеих «Песнях Офелии» искусно воссоздает эти мотивы, менее всего думая о динамике чувств своего лирического героя и перипетиях его любовных отношений с исполнительницей главной роли в достопамятном спектакле. Значительно больше он озабочен чувствами шекспировской героини в интерпретации своей партнерши.

В первых двух катренах первой, стилизованной в народном духе хореической песни она непосредственно обращается к Гамлету, хотя и называет его обобщенно «другом»:

Разлучаясь с девой милой, Друг, ты клялся мне любить!..

Уезжая в край постылый, Клятву данную хранить!..

Там, за Данией счастливой, Берега твои во мгле... Вал сердитый, говорливый Моет слезы на скале... 
В заключительном катрене речь идет о нем же, но уже в 3-м лице, видимо, в знак переключения временных планов и невозможности живого общения с мертвым возлюбленным:

Милый воин не вернется, Весь одетый в серебро...

В гробе тяжко всколыхнется Бант и черное перо...

Вторая песня, написанная довольно прихотливым вольным расшатанным дольником, с рефренным повтором-подхватом двух последних слов 4-го стиха в каждой строфе, в результате чего катрены преобразуются в пятистишия:

Он вчера нашептал мне много, Нашептал мне страшное, страшное...

Он ушел печальной дорогой, А я забыла вчерашнее забыла вчерашнее.

Вчера это было - давно ли? Отчего он такой молчаливый? Я не нашла моих лилий в поле, Я не искала плакучей ивы плакучей ивы.

Ах, давно ли! Со мною, со мною

Говорили — и меня целовали... И не помню, не помню - скрою, О чем берега шептали берега шептали.

Я видела в каждой былинке Дорогое лицо его страшное... Он ушел по той же тропинке, Куда уходило вчерашнее уходило вчерашнее...

Я одна приютилась в поле, И не стало больше печали. Вчера это было - давно ли? Со мной говорили, и меня целовали меня целовали.

(I, 252-253; курсив наш. - О. Ф.) 
Конечно, и на этот раз в уста Офелии вкладывается песня, основанная на народном мелосе и на весьма прихотливой ритмике, но в ней гораздо меньше свойственных фольклору обобщений; в значительной мере они приправлены сюжетной конкретикой, индивидуальными интонациями. Типичную ситуацию роковой любовной разлуки Офелия приноравливает к своему личному горю. Памятуя знаменитую запись в «Дневнике» Блока о том, что «всякое стихотворение - покрывало, растянутое на остриях нескольких слов» и что «эти слова светятся, как звезды», можно заключить: таких «звездных слов» в тексте стихотворении предостаточно; они настойчиво, как в бреду, повторяются на самых ритмически, а, следовательно, и семантически активных местах, складываясь для героини в горестную историю ее погибшей любви.

Заключительным аккордом лирической сюиты А. А. Блока, посвященной «Гамлету», явилось самое громкое, личностное и экспрессивно значимое стихотворение, начатое в 1909 и завершенное 6 февраля 1914 г.

В сущности говоря, перед нами воображаемый ответ Гамлета на песни Офелии, и одновременно ответ прямо отождествляющего себя с ним лирического героя, адресованный предмету переживаемой им любовной страсти.

В первом катрене лирический герой безапелляционно присваивает себе имя и функцию шекспировского героя, лапидарно описывает смятение духа («стынет кровь») перед предельно обобщенным аллегорическом коварством (только что не с заглавной буквы) и также, как и его alter ego, оправдывает свою несомненную вину за гибель Офелии тем, что он сохранил в себе «первую любовь» к ней, «единственной на свете».

Во втором катрене, обращаясь к возлюбленной, покинувшей этот мир, он пользуется эвфемистическим оборотом в сочетании с пушкинским выражением «увел далеко жизни холод» ${ }^{28}$ и констатирует, с одной стороны, реальную гибель Гамлета и, с другой стороны, постигшую его самого духовную катастрофу:

$$
\begin{aligned}
& \text { Тебя, Офелию мою, } \\
& \text { Увел далёко жизни холод, } \\
& \text { И гибну, принц, в родном краю, } \\
& \text { Клинком отравленным заколот. }
\end{aligned}
$$

Итак, разыгранный поэтом в юности спектакль на пару со своей возлюбленной Л. Д. Менделеевой, отразился в его поэзии лирическим циклом из

\footnotetext{
${ }^{28}$ Ср.: «Блажен, кто смолоду был молод, / Блажен, кто вовремя созрел, / Кто постепенно жизни холод / С летами вытерпеть умел» (Пушкин А. С. Евгений Онегин. Гл. 8. Х).
} 
семи стихотворений, представляющих собой творческую интерпретацию великой шекспировской трагедии, спроецированной на лично им пережитую любовную драму, аналогичную взаимоотношениям Гамлета и Офелии, в сочетании с глубоким осмыслением психологических перипетий того высокого чувства, которое М.И. Цветаева в своем «гамлетовском» стихотворении «Офелия — в защиту Королевы» назвала «бессмертной страстью» 29.

Весомый вклад в русскую гамлетиану внесла и А. А. Ахматова, оставившая лирический миницикл из двух миниатюр под общим заголовком «Читая Гамлета» (1909):

1.

У кладбища направо пылил пустырь,

А за ним голубела река.

Ты сказал мне: «Ну что ж, иди в монастырь

Или замуж за дурака...»

Принцы только такое всегда говорят,

Но я эту запомнила речь, -

Пусть струится она сто веков подряд

Горностаевой мантией с плеч.

2.

И как будто по ошибке

Я сказала: «Ты...»

Озарила тень улыбки

Милые черты.

От подобных оговорок

Всякий вспыхнет взор...

Я люблю тебя, как сорок

Ласковых сестер.

(Ахматова, 1965: 10-11)

Заголовок, конечно, говорит сам за себя. В отличие от Блока, артистически эмоционально пережившего судьбу и чувства шекспировского героя, Ахматова воображает себя Офелией умозрительно, как читатель великой трагедии, сочувствующий героине и соучаствующий в творчестве драматурга. Ее лирическая героиня остается самой собой, страстной, своевольной и ироничной, осознает свою историческую удаленность от хронотопа, воссозданного Шекспиром, и с присущей ей непринужденностью вступает в диалогические отношения с литературным созданием далекого прошлого, примерно

${ }^{29}$ Более подробную версию этого фрагмента см.: Федотов, 2017. 
так же, как с возлюбленной Энея Дидоной: «Я не была здесь лет семьсот, / Но ничего не изменилось...» ${ }^{30}$.

Как ошибочно считает О. Ю. Казимирчук, в первом стихотворении ахматовского миницикла чуть ли не впрямую «воспроизводится разговор Офелии с Гамлетом, подстроенный ее отцом, причем происходящее описывается так, как это могло видеться одной Офелии. Описание разговора начинается со значимого отступления от шекспировского текста. В стихотворении дается пейзаж, на фоне которого встречаются герои (“У кладбища направо пылил пустырь, / А за ним голубела река”), тогда как в ремарках Шекспира сообщается только, что герои разговаривают в комнатах» (Казимирчук, 2005).

После столь смелого допущения детали ахматовского пейзажа можно, конечно, трактовать как вечные символы «человеческой смерти и человеческого бессмертия» и утверждать, что Офелия «точно цитирует реплику Гамлета по поводу ее возможного будущего»: «Ты сказал мне: “Ну что ж, иди в монастырь / Или замуж за дурака...”»». По мнению Офелии (и, очевидно, Ахматовой), такие слова мог произнести только принц, лучшим доказательством правомерности этого предположения является то, что в финале сохраненная в памяти фраза превращается в... «королевскую мантию». Приходится, однако, заметить, что точной цитации нет ни в репликах ахматовской Офелии, ни в доводах исследователя. У Ахматовой речь идет не о принце (конкретно, Гамлете), а о «принцах» (вообще), которые «такое всегда говорят».

В анализируемой ситуации ахматовское «Я»ни в малой мере не претендует на полное слияния с объектом его метафорического сопоставления; иначе говоря, речь идет только об одной из многочисленных граней характера ее лирической героини и о вероятностной линии ее поведения в ситуации, описанной Шекспиром. Поэтому столь важны для Ахматовой конкретные детали места и обстоятельств воображаемой сцены. Не где-нибудь, а «у кладбища», «направо» у пыльного пустыря и на фоне голубеющей реки, были услышаны слова, которые некогда Гамлет адресовал Офелии. Понятно, это не то кладбище, на котором по усеченному обряду похоронили девушку, заподозренную в грехе самоубийства, и не тот ручей, в котором она утонула. Просто в плане реального настоящего проигрывается ситуация легендарного прошлого.

В заключительном катрене первого стихотворения лирическая героиня возвращается в свою эпоху, чтобы недвусмысленно прокомментировать слова датского принца так, как будто она реально присутствовала при их произнесении («я эту запомнила речь») и выразить уверенность в том, что эта цар-

${ }^{30} 6$-е стихотворение из цикла «Луна в зените» (там же: 351 ). 
ственная речь протянется «сто веков подряд» «горностаевой мантией». Укоренению первой части миницикла в собственную интимную лирику автора «Вечера» немало способствовал характерный ахматовский дольник с чередованием 4-х и 3-иктных стихов, придающий интонации высказывания непринужденно-раскованный, разговорный характер.

Несколько иначе построена вторая, хореическая, часть диптиха, напоминающая одну из бесчисленных реплик, которыми обмениваются участники никогда не умолкающего любовного диалога. Внешним для нее поводом послужила «как будто оговорка», неожиданный переход, как выразился в свое время Пушкин, от «пустого выl» к «сердечному ты»» ${ }^{31}$. Психологически адекватной оказалась реакция и того, и другой: возлюбленный сдержанно ответил лишь «тенью улыбки», лирическая героиня мысленно перекодировала свою оговорку в знаменитую формулу Гамлета, рокировав предикат сравнения в женскую сторону и не без иронии умерив его чрезмерный гиперболический размах: «Я люблю тебя как сорок / Ласковых сестер» ${ }^{32}$. Основную смысловую нагрузку берет на себя эпитет: «сорок ласковых сестер» не чета сорока тысячам абстрактных братьев, а впоследствии М. И. Цветаева еще больше минимизирует эту арифметическую разницу: «...Как сорок тысяч... - Меньше, / Все ж, чем один любовник».

Страшным образом Офелия аукнулась в последний раз в одном из самых поздних любовных признаний Ахматовой «Предвесенней элегии» (10 марта 1963 г., Комарово), с эпиграфом из сонета Жерара де Нерваля «Обездоленный» («El Desdichado»): «...toi qui m’as consolé» ${ }^{33}$ :

\footnotetext{
Меж сосен метель присмирела, Но, пьяная и без вина,

Там, словно Офелия, пела

Всю ночь сама тишина.

А тот, кто мне только казался,

Был с той обручен тишиной,
}

\footnotetext{
31 Оппозиция “уоu” / “thou” в шекспировскую эпоху уже перестала быть актуальной, но она оставалась таковой для русских переводчиков и русских поэтов. Впрочем, этот непростой вопрос заслуживает специального изучения. Насколько, к примеру, правомерно переводить «Иди в монастырь, / Или замуж за дурака», а не «Идите...»? Или, возможно, мы обязаны делать поправку на то, что «истинные» Гамлет и Офелия разговаривали между собой не по-английски, а по-датски, и не в XVI веке, а гораздо раньше? Но все же, скорее всего, А. А. Ахматова актуализировала русскую традицию, запечатленную А. С. Пушкиным, поскольку ее лирическая героиня не перевоплощалась в Офелию и даже существенно переиначила гиперболу Гамлета: «как сорок ласковых сестер».

32 Хотя М. И. Цветаевой ничего не стоило добавить в начале последней строки хореическое словцо «тысяч».

${ }^{33}$ «Ты, который утешил меня», причем не где-нибудь, а у ночной могилы (“Dans la nuit du Tombeau”).
} 
Простившись, он щедро остался,

Он насмерть остался со мной.

(Ахматова, 2005: 215-216)

Поющая Офелия присутствует в стихотворении только лишь как исключительно выразительное сравнение. Ночь напролет за нее безмолвно поет «сама тишина», с которой «обручен» вечный и неуловимый персонаж любовной лирики Ахматовой. Особенно впечатляет ударная концовка с пошекспировски экспрессивными наречиями: «Простившись, он щедро остался, / Он насмерть остался со мной». Видимо, в представлении Ахматовой, только ее Гамлет мог вот так безоглядно навсегда («насмерть»!) остаться с Офелией, чего не удостоил ее Гамлет шекспировский.

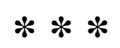

Наконец, самый свежий и, очевидно, наиболее сильный творческий импульс М. И. Цветаева получила от «Уроков английского» Б. Л. Пастернака, написанных в 1917 и опубликованных в 1922 г. Как исключительно точно показали В. Н. Альфонсов и С. Н. Бройтман (Альфонсов, 1990: 77-80; Бройтман, 2007: 321-325), весь текст этого замечательного произведения насквозь пронизан многоярусным параллелизмом: между двумя шекспировскими героинями, исполняющими, как нарочно, «в момент перехода в новое состояние духа», в наитии «последнего откровения» навеянные фольклором песни про плакучую иву, которая, по меткому слову А. А. Фета, приходится им обеим «сестрой» ${ }^{34}$; между деревом, не сулящим ни спокойствия, ни долгой благополучной жизни, и двумя обреченными прекрасными женщинами, предчувствующими вслед за утратой любви неминуемую утрату жизни; и даже между предметными обстоятельствами их гибели в образных деталях (одной гнездящийся в ее имени «чернейший демон» «псалом плакучих русл припас», т. е. тоже позвал на дно, а другая «канула» в реальный ручей «с охапкой верб и чистотела»), хотя по сюжету «своей» трагедии Дездемона, в отличие от Офелии, рассталась с жизнью в собственной спальне. Пастернаку важно было подготовить и ту и другую к входу «с сердца замираньем» в уготованный им «бассейн вселенной», чтоб «стан свой любящий / Обдать и

\footnotetext{
34 Что, кстати, весьма органично согласуется с заголовком книги стихов Б. Л. Пастернака и его францисканскими настроениями, навеянными если не непосредственно сочинениями великого итальянца (в 1913 г. они вышли в русском переводе с предисловием С. Н. Дурылина - Цветочки ... , 1913, а сам Дурылин имел немалое влияние на поэта), то во всяком случае - отраженным светом - его учением, получившим тогда необычайную популярность в России. Ср.: Рашковская, 1992; Жолковский, 2005; Гардзонио, 1999; Исупов, 2001.
} 
$\overline{\text { оглушить мирами» }(126)^{35} \text {. Этот акт С. Н. Бройтман трактует как пассивную }}$ антитезу по отношению к активной интенции мужского начала, искони стремящегося не отдаться стихиям, а «самому овладеть миром»: «...мирозданье - лишь страсти разряды, / Человеческим сердцем накопленной» (Бройтман, 2007: 325).

Пастернак, с его откровенно растительной фамилией, вообще был склонен не разъединять человека с природой, а наоборот по-родственному сливать его с ней. Метафорически олицетворенная ива, и без влияния Шекспира, всегда находилась в ближайшем родстве с его лирическими героями: то ее ветви нависали над сложившим весла гребцом и целовали «в ключицы, / В локти, в уключины» (123), то - значительно позже - она олицетворяла, в глазах поэта, весну в простонародной телогрейке: «Это она, это она, / Это ее чародейство и диво, / Это ее телогрейка за ивой, / Плечи, косынка, стан и спина. / Это Снегурка у края обрыва. / Это о ней из оврага со дна / Льется без умолку бред торопливый / Полубезумного болтуна» («Опять весна», 1941) (405), то, наконец, во время той же «весенней распутицы» он видит, как «...ива вдовий свой повойник» «клонила, свесивши в овраг...» (скорее всего, в тот же самый) (Стихи Юрия Живаго. «Весенняя распутица», 1953) (429).

Удивительно ли, что ее подернутый траурными коннотациями образ с пронзительной лиричностью привычно педалируется Пастернаком в его переводе песенки Дездемоны, поющей ее в предчувствии недоброго накануне встречи с Отелло:

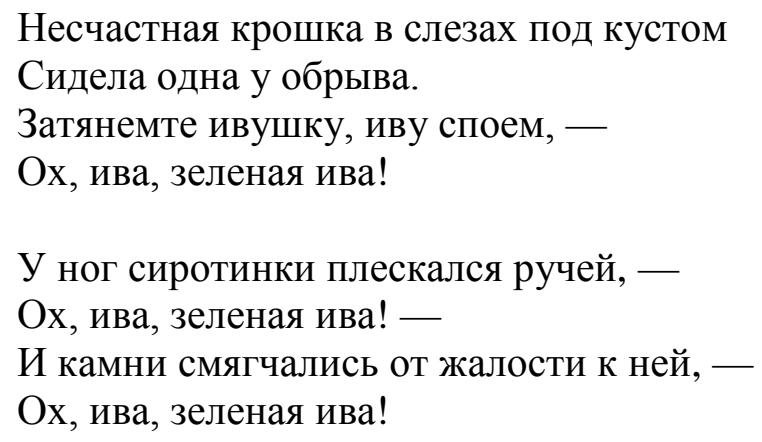

(Шекспир, 1960: 394-395)

Совершенно в ином, мужском, амплуа Пастернак вместе со своим лирическим героем предстал в одном из самых концептуальных своих стихотворений — «Гамлете» (<1946>), написанном несколько лет спустя после окончания работы над переводом великой трагедии.

\footnotetext{
35 Здесь и далее, если не указано иное, стихотворные тексты Пастернака цитируются с указанием страниц в круглых скобках по изданию: Пастернак, 1965.
} 
Ситуация с самого начала обозначена более чем определенно: вслед за тем, как затих гул воображаемых аплодисментов, опять же на воображаемую сцену, вполне возможно и в собственном доме, выходит лирический герой, поэт и артист в одном лице, вживающийся в роль Гамлета для того, чтобы, «прислонясь к дверному косяку», выведать «в далеком отголоске» шекспировской трагедии свою грядущую судьбу. Он ощущает на себе пронзительные взгляды едва ли не всей вселенной (звездное «кантовское» небо отнюдь не сочувственно изучает его «тысячью биноклей на оси»). Он прекрасно отдает себе отчет в том, что ожидает его в роли Гамлета, почему и приходит ему на ум отчаянная молитва Христа в Гефсиманском саду (Мк. 14:36). Пастернак отнюдь не уравнивает свое лирическое Я ни с Богочеловеком, ни даже с мнимым автором этого стихотворения - Юрием Живаго. Согласившись играть эту роль, он в то же время отчетливо видит разницу между трагической участью датского принца и тем, что уготовано ему самому: «Но сейчас идет другая драма, / И на этот раз меня уволь».

Но продуман распорядок действий, И неотвратим конец пути.

Я один, все тонет в фарисействе.

Жизнь прожить — не поле перейти.

(Пастернак, 2004: 515)

Немалую долю к содержательной информации добавляет метрическая форма стихотворения, написанного 5-стопным хореем, размером, обладающим вполне определенной репутацией, которую К. Ф. Тарановский определил как дихотомию динамического мотива пути и статического экзистенционального раздумья о смысле жизни (и смерти) (Тарановский, 1963), да еще в сопровождении ключевого глагола движения: «Я вышел на подмостки». Ср.: «Выхожу один я на дорогу...» (М. Ю. Лермонтов), «Вот иду я вдоль большой дороги...» (Ф. И. Тютчев), «Выхожу я в путь открытый взорам...» (А. А. Блок), «Выххожу я на высокий берег...» (С. А. Есенин), «Выходила на берег Катюша...» (М. В. Исаковский). Лирический герой Б. Л. Пастернака, вообразивший себя Гамлетом, размышляет о вероятном векторе своего жизненного пути и о его неизбежном трагическом финише.

Уже состоялся телефонный разговор со Сталиным о судьбе опального О.Э. Мандельштама, а затем просочилось и глухое известие о его гибели, уже недалеко от Чистополя, где провел военные годы Б. Л. Пастернак, покончила с собой в Елабуге М. И. Цветаева, уже сам поэт ощутил на себе и на своих близких зловещую подозрительность тоталитарного режима и уже год, как началась работа над «Доктором Живаго»... Противостояние одинокого 
поэта морю окружавшего его фарисейства наметилось сначала исподволь, перманентно продолжилось и известно чем завершилось. То, что искал поэт «в далеком отголоске» прошлого, обернулось не в пример более тяжким жребием, который он провиденциально различил в грядущем.

\section{$* * *$}

Оригинальную трактовку гениальной шекспировский трагедии, этого, по словам В. Г. Белинского, «блистательнейшего алмаза в лучезарной короне царя драматических поэтов», находим в ранней поэме И. А. Бродского «Шествие», 1962. То, что Шекспир волновал воображение поэта всегда, очевидным образом отразилось в его диалогах с С. М. Волковым. Конечно, в первую очередь его занимали проблемы стихопоэтики. В частности, когда речь заходит об «идиоматическом» пристрастии Роберта Фроста к белому 5-стопному ямбу, он замечает, что самый ходовой размер в метрическом репертуаре поэта, поистине «хлеб и вода» английской поэзии, генетически связан с творчеством Шекспира. Аналогичную роль в русской поэзии, полагает Бродский, играл 4-стопный ямб.

Весьма скептически отнесся он к пастернаковским переводам «из Шекспира» (сонетов и практически всех его великих трагедий: «Гамлета», «Ромео и Джульетты», «Отелло», «Короля Лира», «Макбета», «Антония и Клеопатры», а также 1-й и 2-й части исторической хроники «Генрих IV»): «...они, конечно, замечательны, но с Шекспиром имеют чрезвычайно мало общего. Очевидно тональность английского стиха русской поэзии в сильной степени чужда» (Волков, 2000; гл. VII).

Собственно о «Гамлете» И. А. Бродский вспоминает, отмечая интертекстуальное взаимодействие между ним и поразившим его стихотворением Е. А. Баратынского «Запустение», в которых воспроизводится архетипическая ситуация рандеву сына с покойным отцом ${ }^{36}$.

Наиболее, однако, обстоятельно и концептуально проблематика «Гамлета» дает о себе знать в поэме «Шествие», где уже в авторском Предисловии следует отсылка к III акту трагедии, в начале которого задумавший вывести убийцу своего отца на чистую воду принц Гамлет дает наставление бродячим актерам. Он просит их произносить слова придуманного им текста сдержан-

\footnotetext{
36 Эту ситуацию И. А. Бродский, по всей видимости, неоднократно примерял и на себя как лично его коснувшуюся, о чем свидетельствует лейтмотивное отождествление его лирического героя с Одиссеем. Среди других литературных аналогов его внимание могли привлечь пасхальные стихотворения В. В. Набокова, последовавшие после трагической гибели отца поэта: «Пасха» («Я вижу облако сияющее, крышу...»), «Гекзаметры» («Смерть это утренний луч, пробужденье весеннее, верю...»), «Вечер на пустыре» («Вдохновенье, розовое небо...») и др. Подробнее см.: Федотов, 2014: 93-101.
} 
но, без аффектированного надрыва и чрезмерной жестикуляции, чтобы сцена «Мышеловки» произвела должное впечатление на Клавдия.

Но еще важнее включение фигуры заглавного и, как считается, самого автобиографического шекспировского героя в состав условных персонажей поэмы. Уже во 2-й главке он вводится в действие вслед за князем Мышкиным, Лжецом, Дон-Кихотом, Королем и Честнягой:

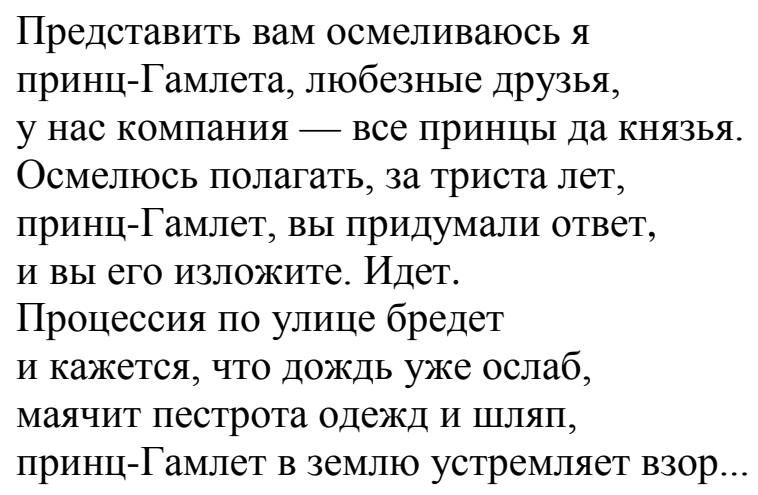

(Бродский, 2001: 81)

Авторская ремарка при представлении Гамлета с предположением, что за минувшие триста лет принц-таки придумал ответ на экзистенциальную дилемму, который ему предстоит изложить через некоторое время, воспринимается как пролог к его сольному романсу в одной из заключительных главок поэмы. Пока же шекспировский персонаж устремляет свой взор в землю, туда, куда уходит его возлюбленная, еще раньше ее ушел нянчивший его королевский шут Йорик, где пролегает граница между жизнью и смертью.

В 3-й главке принц мелькает в той же компании между Крысоловом и Лжецом. Очень косвенно отзвук трагедии Шекспира слышится в 7-й главке, представляющей собой комментарий к предыдущему «Романсу Поэта», а именно в стихе «Все таковы. Да, все слова, стихи...» (там же: 89), намекающем на многозначительный ответ Гамлета на вопрос Полония: «Что вы читаете, мой принц?»: «Слова, слова, слова». Мотив «слов» будет эпизодически возникать и в дальнейшем, например, в 11-й главке, где речь идет о том, что «...ложь и правда, кажется, одно, / что лживые и честные слова / одна изобретает голова, / одни уста способны их сказать, / чему же предпочтенье оказать. / Как мало смысла в искренних словах...» (там же: 93) и, особенно, в 25-й главке, формально комментарии к «Романсу Честняги и Хора», а на самом деле лирическом отступлении автора-повествователя, обращенном к самому интимному, самому сокровенному: 


\begin{abstract}
Стихи мои, как бедная листва. К какой зиме торопятся слова. Но как листву — испуганно лови вокруг слова из прожитой любви, и прижимай ладони к голове, и по газонной согбенной траве спеши назад - они бегут вослед, но кажется, что впереди $u x$ нет.
\end{abstract}

Таким образом, рассыпанные по нескольким главкам «слова», в совокупности образуют знаменитую гамлетовскую максиму, ставшую крылатой, сопряженную к тому же с ее окказиональным синонимом - «стихами». В очередной раз, не в лирическом, однако, контексте, а в нарративном дискурсе 21-й главки, шекспировский герой напоминает о себе снова в компании уже примелькавшихся спутников в характерной «сценической» позе: «...принц Гамлет руки сложит на груди...» (там же: 105).

Наконец собственно «Романс принца Гамлета», составляющий одну из финальных главок поэмы. Он мог бы получить и более точное жанровое определение - «Монолог принца Гамлета», поскольку интегрирует едва ли не все концептуальные высказывания заглавного персонажа трагедии, если не дублирующего Шекспира, то, по крайней мере, выступающего в роли своеобразного лиро-драматического героя, несущего в себе немалую толику авторского сознания. Такова же, в конечном итоге, творческая стратегия Бродского как автора поэмы-мистерии, предстающего перед читателем в разнообразных персонифицированных ипостасях.

Авторское сознание «Шествия», таким образом, можно представить в виде сконструированного по античным образцам Хора из двадцати участников некой процессии, символизирующей бесконечный поток жизни. Они исполняют разные романсы, «по существу, монологи»; и исполняют их далеко не в унисон. Такому синтетическому Хору свойственно полифоническое многоголосие, типологически близкое тому, какое выявил М. М. Бахтин в романах Ф. М. Достоевского. На фоне разноголосицы условных персонажей, выражающих тот самый «банал», гимн которому являет собой идея поэмы, выделяются голоса излагающего событийный план отстраненного нарратора, неотделимого от незримо причастного к действию сугубо автобиографического героя, переживающего любовную драму, и Гамлета, может быть, единственного персонажа, с которым Бродский, также как и Шекспир, мог бы разделить авторство своего произведения.

В финале 1-й главки, после представления основных персонажей (Арлекина, Коломбины, Скрипача, Плача, Усталого Человека и - наиболее об- 
стоятельно - Поэта), упоминается загадочный безымянный Герой, который, казалось бы, никак себя не проявляет, «молчит, / не говорит, не шепчет, не кричит, / прислушиваясь к возгласам других, / не совершает действий никаких» (там же: 80), но автору-повествователю он не безразличен: «Я попытаюсь вас увлечь игрой: / никем не замечаемый порой, / запомните - присутствует герой» (там же). Скорее всего, это предельно обобщенный герой, так сказать, всех времен и народов, в котором каждый может увидеть себя самого...

Чем же родствен Гамлет авторской индивидуальности И. А. Бродского? Прежде всего, конечно, мотивом изгнания (Клавдий от греха подальше отправляет его из родной Дании в Англию на верную гибель) и трагическим переживанием любовной катастрофы, граничащим с безумием. В самом начале своего романса Гамлет выражает недоумение по поводу того, «Как быстро обгоняют нас / возлюбленные наши. / Видит Бог...» (там же: 130). Три графически выделенных стиховых ряда объединены акаталектикой, а, следовательно, отсутствием между ними разграничительных метрических зазоров, и единственным рифмочленом, коррелирующим со своим контрагентом в следующем стихе: «...но я б так быстро добежать не смог / и до безумья» (там же). Иными словами, с самых первых стихов обнаруживается тенденция к перераспределению границ между стихами и синтаксическими звеньями, которая оптимально организует речевой поток, отличающийся «некоторыми длиннотами» и требующий при декламации «произнесения с максимальной экспрессией».

Таким образом, 1-й стих, состоящий из трех графически обособленных звеньев, фактически насчитывает 9 стоп, хотя отмеченный конфликт между синтаксисом и метром допускает и другой, не столь экзотический вариант членения: 4-стопный холостой стих в сочетании с базовым 5-стопником: «Как быстро обгоняют нас / возлюбленные наши. Видит Бог...» (там же). В обоих случаях удается избежать вкрапления в безраздельно господствующую ямбическую каденцию контрастного хореического фрагмента «Видит Бог» ${ }^{37}$.

Шекспировский «Гамлет», как, впрочем, и все пьесы драматурга, написан, в основном, белым 5-стопным ямбом. Но не полностью. Время от времени доминирующий размер уступает контрастно звучащим зарифмованным фрагментам, чаще всего двустишиям, выполняющим роль пуанта в заверше-

\footnotetext{
${ }^{37}$ Во второй половине стихотворения в аналогичных стихах «Как быстро обгоняют нас / возлюбленные наши. / В час безумья...» (там же) таким же ломающим ритм фрагментом представляется заключительное звено «В час безумья», но, воссоединившись с предшествующим стихом, оно видоизменяет свое метрическое строение: «Возлюбленные наши в час безумья» (Я5).
} 
нии эффектных монологов или сцен. Попарно срифмованными стихами, имитирующими александрийский стих, Гамлет пишет и сцену «Мышеловки», а после ее исполнения, обмениваясь впечатлениями с Горацио, прибегает к торжествующим катренам разностопного ямба с перекрестной рифмовкой:

Why, let the stricken deer go weep,

The hart ungalled play.

For some must watch, while some must sleep,

Thus (So) runs the world away.
Пусть пораженный красный зверь идет рыдать,

Олень-самец задет игрой.

Одни должны следить, другие - спать:

Так мир сбегает прочь - долой.

(пер. И. В. Пешкова)

И после обмена прозаическими репликами о возможности записаться в «актерское товарищество» даже не на полпая, а на целый пай, выдает еще один катрен с холостым стихом:

For thou dost know o Damon deer,

This realm dismantled was

Of Jove himself, and now reigns here.

A very very payjock.
Ты должен знать, Дамон, мой дорогой, Обнажено Иовом царство - опа!

А правит кто-то здесь другой -

Ну полная он - жар-птица.

(пер. И. В. Пешкова)

На что Гораций, повинуясь установившейся у него в общении с принцем шутливой тональности, вставляет очередную приправленную острой аттической солью реплику: "You might have rhymed” [«Мог бы и срифмовать»], прозрачно намекая на скрытую обсценную рифму (Шекспир, 2003а: 84, 83) ${ }^{38}$.

Шекспировский Гамлет переживает одновременно несколько трагических коллизий: кризис гуманистического мировоззрения на исходе эпохи Возрождения, потерю отца, взывающего к мести, вынужденный отказ от любви, которой приходится пожертвовать ради достижения высокой цели, безумие, а затем и гибель возлюбленной, необходимость вступить в неравную борьбу “against a sea of troubles” («против моря бед»), и, наконец, осознание того, что поставленную им перед собой задачу в одиночку выполнить невозможно: «Порвалась дней связующая нить, / Как мне обрывки их соединить!» (пер. Б. Л. Пастернака).

Все это в совокупности доводит Гамлета до имитации безумия, а Офелию, на которую обрушились сразу и разрыв с возлюбленным, и смерть отца от его руки, сводит с ума на самом деле. Поэтому свой «Романс принца Гам-

\footnotetext{
${ }^{38}$ Несколько другой, смягченный вариант перевода предлагают М. Л. Лозинский: «Мой милый Дамон, о поверь, / На этом троне цвел / Второй Юпитер; а теперь / Здесь царствует — павлин» и Б. Л. Пастернак: «Ты знаешь, дорогой Дамон, / Юпитера орел / Слетел с престола, и на трон / Воссел простой осе...тр».
} 
лета» Бродский начинает с парадоксального соперничества между влюбленными: кто быстрее добежит до безумия, а в подтексте - и до смерти:

Как быстро обгоняют нас возлюбленные наши.

Видит Бог, но я б так быстро добежать не смог и до безумья.

(Бродский, 2001: 130)

Затем он видимо вспоминает о своей родине Дании: «...вот Дания моя при ветерке, / Офелия купается в реке», отправляясь в Англию («Я - в Англию»; там же), где по остроумному замечанию могильщика, он может сойти за своего: его сумасшествие не будет бросаться в глаза, поскольку там все люди такие. Как бы отвечая на сакраментальный риторический вопрос: “То be, or not to be, that is the question...”, Бродский устами Гамлета, можно сказать, персонифицированного лирического героя Шекспира, исключает его нормальную жизнь на родине, не в Дании, конечно, а в Англии и — в известном смысле - ...в России:

Я - в Англию.

Мне в Англии НЕ БЫТЬ. ЯПЯПЯ

Кого-то своевременно любить, ЯПЯПЯ

кого-то своевременно забыть, ЯПЯПЯ

кого-то своевременно убить, ЯПЯПЯ

и сразу непременная тюрьма - ЯПЯПЯ

и спятить своевременно с ума. ЯПЯПЯ

(там же)

Страстная, экстатическая тирада принца получает дополнительную экспрессию благодаря не только строго выдержанному интонационно-синтаксическому параллелизму, но и массированному нагнетанию самой гармоничной, фоновой для всего романса ритмической формы 5-стопного ямба, адекватной пеону II. В том же направлении действует длинная четырехчленная рифменная цепь, нарушающая инерцию двустиший парной рифмовки: «не быть - любить - забыть - убить» ${ }^{39}$.

${ }^{39}$ Впрочем, рифмовку этого четверостишия можно интерпретировать и как перекрестную, различая рифмы по твердости («не быть - забыть») и мягкости («любить - убить») опорных согласных. В таком случае контраст с доминирующей парной рифмовкой только усугубляется. Заметим также, что первый член этой рифмы в любом случае тавтологически рифмуется с концептуальным гамлетовским вопросом: “Тo be or not to be” («Быть или не быть») и тем самым дает однозначно отрицательный ответ на него: «Мне в Англии НЕ БЫТЬ». Концентрацию характерных формул «инфинитивного письма», генетически восходящих к монологу Гамлета, А. К. Жолковский рассматривает как косвенную авториза- 
«Рифмой наглагольной» «гнушались» еще в пушкинские времена, и автор «Домика в Коломне» в своих метапоэтических размышлениях о структуре октавы выражал готовность реабилитировать их: «К чему? скажите, уж и так мы голы. / Отныне в рифмы буду брать глаголы». В данном случае исключительно точная «наглагольная рифма» - не слабость, а сила, ибо она энергично уравнивает действия - слагаемые всего того, что противоречит самому бытию в пределах истинной родины лирического субъекта, совмещающего в себе приметы датского принца, автора английской трагедии о нем и персонифицированного заместителя многоликого русского повествователя в «Шествии». В результате оформляется чеканное метафорическое уравнение: «НЕ БЫТЬ в Англии (России или вообще - потенциальному изгнаннику — на родине)» - значит «Кого-то своевременно любить», затем «забыть» и тем самым, получается, «убить», после чего - как следствие - «непременная тюрьма — / И спятить своевременно с ума». Наречие «своевременно», повторяемое многократно, переосмысляется во «всегда» или, иначе, во все времена. Мотив тюрьмы, сопряженный с мотивом безумия, неминуемо влечет за собой ассоциации с Данией, которая, как выясняется в разговоре Гамлета с Розенкранцем и Гильденстерном, наихудшая из темниц мировой тюрьмы.

Монолог своего Гамлета И. А. Бродский строит как исступленную речь героя, утратившего любовь, веру и надежду в успех объявленной им в одиночку войны всему миру. Одновременно это и «придуманный» символическим героем ответ на собственный трагически-риторический вопрос, на который с самого начала настраивал его автор-повествователь. Имитируя безумие, он ощущает его симптомы, подобно Офелии, на самом деле. Перед его умственным взором мелькают призрачные видения, которые он фиксирует многократным повтором указательного местоимения «вот»: «Вот Дания...» (дважды), «А вот ее король. / Когда-нибудь и мне такая роль...» и, наконец, «БЕЗУМИЕ — вот главное во мне» (там же: 130-131). Приливами наплывающего безумия мотивируются и другие концептуально значимые повторы, возвращающиеся наподобие идеи фикс:

цию И. А. Бродским «Романса принца Гамлета», полагая при этом, что сам он «строится не на проблематике сна / смерти, а исключительно на мотиве быть / не быть, с выводом в пользу небытия, и весь свой инфинитивный потенциал черпает именно отсюда. Помимо этого мотива в "Романсе принца Гамлета" и его остальных инфинитивных проекциях тематически акцентируются не разрабатываемые в "Монологе Гамлета", но характерные для "Гамлета" в целом, мотивы любви, убийства, а также эмигрантская avant la lettre проблематика разлуки с родиной, по-видимому, уже занимавшая Бродского. Именно в этом, как представляется, была соль свободного и притом лирического поворота гамлетовской темы» (Жолковский, 2009: 169, 171). 
Не быть иль быть - вопрос прямолинейный мне задает мой бедный ум, и нервный все просится ответ: не быть, НЕ БЫТЬ, кого-то своевременно забыть, кого-то своевременно любить, кого-то своевременно... Постой! Не быть иль быть! - какой-то звук пустой. Здесь все, как захотелось небесам, А, впрочем, говорил об этом сам.
ЯЯЯПЯ

ПЯЯЯЯ

ЯПЯЯЯ

ЯПЯПЯ

ЯПЯПЯ

ЯПЯПЯ

ЯЯЯЯЯ

ЯПЯПЯ

ЯПЯПЯ

Эмоциональная напряженность гамлетовского монолога находит адекватное выражение в его синтаксической и метроритмической организации. С одной стороны, бросается в глаза слоговая неравномерность и неравновеликость 27(28) предложений, из которых состоит текст «Романса»:

$15-18-13-30-\underline{-4}-5-50-3-6-10-4-6-10-15-34-40-10-25-\underline{5-60-2-4-6}-40-10-8-9(+1)=442$

Два самых протяженных периода в 50 и 60 слогов закономерно соседствуют с укороченными эмоциональными всплесками (от 2-х до 6-ти слогов), особенно во втором случае: «Постой!» (2) / «Не быть иль быть! (4) - какойто звук пустой» (6). Действительно, это предельно эмфатический дискурс в устах эмоционально неуравновешенного, взволнованного человека.

Ровно также не отличается спокойной монотонной интонацией доминирующий в тексте 5-стопный ямб парной рифмовки. Всего стихотворение насчитывает 45 стихов, если считать от рифмы до рифмы; при этом текст членится на 53 графических ряда, в числе которых в качестве заключительного обособленного стиха в один слог оказывается заглавное слово следующего стихотворения: «Черт».

В основном это 5-стопный нецезурованный ямб с мужскими окончаниями парной рифмовки. Один из двух удлиненных 9-стопных стихов приходится считать холостым: «Как быстро обгоняют нас / возлюбленные наши. В час безумья...», хотя он мог бы срифмоваться с тремя последующими стихами: «...мне кажется - еще нормален я, / когда давно Офелия моя / лепечет язычком небытия» (там же: 130), если бы финальное слово было задействовано не в краткой, а полной форме «безумия», получив отягощение на последнем слоге.

Кроме того ровное ритмическое движение доминирующего размера прерывается четырьмя укороченными, 4-стопными стихами: 
...мне, кажется, пора домой.

$<\ldots>$

...еще внизу,

а сверху мы - приправа.

$<\ldots>$

Позор на Скандинавский мир.

$<\ldots>$

Далеко ль до конца, милорд.

(там же: 130-131)

Однако еще чувствительнее возмущающее воздействие чужеродных в потоке акаталектического мужского ямба пяти женских стихов; один из них, как мы уже видели, 9-стопный: «Как быстро обгоняют нас / возлюбленные наши. / В час безумья...», еще один - 4-стопный: «...еще внизу, / а сверху мы - приправа» и три стандартных 5-стопника: «...огурчики - налево и направо...», «Не быть иль быть — вопрос прямолинейный...» и «...мне задает мой бедный ум, и нервный...». Все они в той или иной мере вносят диссонанс в гиперметрические акаталектические цепи, в которых чередование ямбических стоп не прерывается на клаузулах лишними слогами. Самая длинная цепь такого рода - от зачина до окончания первого женского стиха насчитывает 97 непрерывно следующих друг за другом - стык в стык - ямбических стоп. Она образует томительно длящуюся взволнованную риторическую тираду, обрывающуюся именно на внезапно появившейся женской клаузуле.

После некоторой заминки и естественной паузы разворачивается следующая гиперметрическая цепь акаталектических ямбов в 50 стоп в промежутке между стихами «...мне кажется - еще нормален я...» и «...огурчики - налево и направо...». В сознании Гамлета, исполняющего роль лирического героя, в этот момент проносится видение эльсинорского кладбища в сопровождении сразу четырех аномальных женских стихов подряд от упомянутых «огурчиков» до «...мне задает мой бедный ум, и нервный...». Далее, уже до конца, совпадающего с заголовком следующего стихотворения «Черт», продолжается еще один приступ гамлетовской исповеди, насчитывающий еще 68 неукоснительно следующих друг за другом ямбических стоп.

Правда, заключительная тирада осложнена другими возмутителями ровного ритмического движения, а именно: резкой внутристиховой паузой в повторном перечислении того, что значит «не быть»: «...кого-то своевременно забыть, / кого-то своевременно любить, / кого-то своевременно...», двумя укороченными восклицаниями после обрыва перечисления, столь же отрывистой констатацией акустической пустоты вопроса, утратившего свою вопросительную модальность, вопроса, роковым образом не имеющего ответа, 
твердой интонацией полноударного стиха: «Быть иль не быть! - какой-то звук пустой» и, наконец, очевидной ритмической турбулентностью в пяти финальных стихах.

На фоне ровной череды предшествующих, идущих подряд четырех стихов базовой модели 5-стопного ямба ЯПЯПЯ:

Здесь все, как захотелось небесам. Я, впрочем, говорил об этом сам. Гораций мой, я верил чудесам, которые появятся извне.
ЯПЯПЯ

ЯПЯПЯ

ЯПЯПЯ

ЯПЯПЯ

(там же: 131)

следует будоражащий сгусток из самых необычных ритмических форм финального аккорда:

$\begin{array}{ll}\text { БЕЗУМИЕ - вот главное во мне. } & \text { ЯПСПЯ } \\ \text { Позор на Скандинавский мир. } & \text { ЯПЯЯ } \\ \text { Далеко ль до конца, ВИЛЬЯМ ШЕКСПИР? ЯПЯЯЯ } \\ \text { Далеко ль до конца, милорд. } & \text { ЯПЯЯ } \\ \text { Какого чорта, в самом деле... } & \end{array}$

(там же)

Действительно, практически в каждом стихе здесь нас подстерегает сюрприз: форма со спондеем в центре чрезвычайно важного по смыслу стиха, сигнализирующего о добровольном безумии героя в этом безумном мире («БЕЗУМИЕ - вот главное во мне»), два стиха 4-стопного ямба исключительно редкой формы с пиррихием на 2-й стопе, один стих также слабо представленной в контексте данного стихотворения формы 5-стопного ямба с пиррихием на 2-й стопе (всего 4 употребления) и наиболее экзотический завершающий составной стих, представляющий собой полноударный пятистопник с парадоксальным анжамбеманом на паузе внутри последней стопы, образованный слиянием оборванного восклицания «Какого чорта, в самом деле...» и драматургической ремарки-заголовка, возвещающей о появлении следующего персонажа «ЧОРТ!».

«Романс принца Гамлета» в исполнении Бродского завершается весьма неожиданно. Разыграв безумие, датский принц переживает его как позор «Скандинавского мира» и обращается к исконному автору бессмертной трагедии «милорду Вильяму Шекспиру» с риторическим вопросом «далеко ль до конца» то ли трагедии, то ли своего земного бытия, то ли вообще жизни на земле. Но неожиданно обрывает себя на полуслове, апеллируя к... черту. Тот, как ему и положено, нежданно-негаданно является. Обнажая прием, поэт пе- 
ренимает творческую инициативу у английского гения. Перевоплотившись в его наиболее автобиографического героя, он получает возможность обратиться к нему лично, поскольку трагические коллизии, побудившие Гамлета пожертвовать личным счастьем и ополчиться против «моря зла», остались актуальными по сей день.

Версификационная партитура замечательным образом соответствует содержанию и жанровой специфике гамлетовского монолога. Это действительно взволнованная ораторская тирада, с приливами и отливами эмоционального напряжения, чередованием разновеликих периодов как в синтаксическом, так и ритмическом измерении, исключительно выразительной паузировкой, лексическими и фразовыми, горизонтальными и вертикальными повторами.

Столь изощренный диалог солирующего инструмента смысла с многоуровневым оркестром плана выражения, конечно же, не был следствием осознанной интеллектуально-аналитической работы автора, рационально строящего свой текст. Сам И. А. Бродский объяснил бы достигнутый резонанс просто: язык подсказал, а вдохновение помогло поэту его услышать и мастерски воплотить в тексте.

\section{СПИСОК ЛИТЕРАТУРЫ}

Александр Блок в воспоминаниях современников (1980) : в 2 т. М. : Художественная литература. Т. 1. 552 с.

Альфонсов, В. Н. (1990) Поэзия Б. Пастернака. Л. : Советский писатель. $368 \mathrm{c}$.

Анненский, И. Ф. (1979) Книга отражений. М. : Наука. 691 с.

Античная лирика (1968) / пер. с древнегреч. и латин. М. : Художественная литература. $623 \mathrm{c}$.

Антокольский, П. Г. (1988) Театр Марины Цветаевой // Цветаева М. И. Театр. М. : Искусство. 380, [2] с. С. 5-22.

Арабская поэзия средних веков (1975) / сост., послесл. и примеч. И. М. Фильштинского. М. : Художественная литература. 767 с.

Ахматова, А. А. (1965) Бег времени. М. ; Л. : Советский писатель. 468, [4] c.

Ахматова, А. А. (2005) Четки. Anno Domini. Поэма без героя. М. : ОЛМА-ПРЕСС. $478 \mathrm{c}$.

Ашукин, Н. С. (1929) Валерий Брюсов. В автобиографических записях, письмах, воспоминаниях современников и отзывах критики. М. : Изд-во Федерация. $400 \mathrm{c.}$

Белый, А. (1922) Воспоминания об Александре Александровиче Блоке // Записки мечтателей. № 6. Пб. : Алконост. 182, [2] с. С. 5-122.

Блок, А. А. (1980) Собр. соч. : в 6 т. Л. : Художественная литература. 
Блок, А. А. (1997) Полн. собр. соч. и писем : в 20 т. М. : Наука. Т. 1. 631 c.

Бродский, И. А. (1991) Путешествие в Стамбул // Петрополь-3 : Альманах. Л. : Союз кинематографистов СССР. 216 с. С. 36-49.

Бродский, И. А. (1999) Меньше единицы : избранные эссе / пер. с англ. М. : Независимая газета. 472 с.

Бродский, И. А. (2001) Шествие // Бродский И. А. Сочинения Иосифа Бродского : в 7 т. / ред. Я. А. Гордин ; сост. Г. Ф. Комаров. СПб. : Пушкинский фонд. Т. 1 : Стихотворения 1957-1963 гг. 304 с. С. 79-133.

Бройтман, С. Н. (2007) Поэтика книги Бориса Пастернака «Сестра моя - жизнь». М. : Прогресс-Традиция. 608 с.

Брюсов, В. Я. (1973а) Собр. соч. : в 7 т. М. : Художественная литература. Т. 1 : Стихотворения. Поэмы. 1892-1909. 672 с.

Брюсов, В. Я. (1973b) Собр. соч. : в 7 т. М. : Художественная литература. Т. 2 : Стихотворения 1909-1917. 496 с.

Вийон, Ф. (1998) Полн. собр. поэтических сочинений / пер. с франц. ; вступ. статья, сост., коммент. Е. В. Витковского. М. : РИПОЛ классик. 448 с.

Волков, С. М. (2000) Диалоги с Иосифом Бродским. М. : Независимая газета. 325, [2] с.

Гардзонио, С. (1999) «Сестра моя - жизнь» Б. Л. Пастернака и наследие св. Франциска Ассизского // Stanford Slavic Studies. Vol. 21: Poetry and revolution. Boris Pasternak's My Sisters — Life / ed. by L. Fleishma. Stanford : [S. n.]. 244 p. P. $66-75$.

Горбунов, А. Н. (1985) Комментарии // Шекспир У. Гамлет. Избранные переводы : сб. / сост., пред. и комм. А. Н. Горбунова. М. : Радуга. 640 с. C. $579-640$.

Жолковский, А. К. (2005) Книга книг Пастернака // Жолковский А. К. Избранные статьи о русской поэзии: инварианты, структуры, стратегии, интертексты. М. : РГГУ. 652, [3] с. С. 175-194.

Жолковский, А. К. (2009) Новая и новейшая русская поэзия. М. : РГГУ. 369 c.

Записки наблюдателя (1924) : лит. сб. Кн. 1 / под ред. Д. Н. Крачковского, А. А. Несси. Прага : Чеш.-рус. изд-во. 256 с.

Исупов, К. Г. (2001) Франциск из Ассизи в памяти русской культуры // Филологические исследования : сб. науч. работ. Вып. 3. Донецк : ЮгоВосток. 380 с. С. $50-79$.

Казимирчук, О. Ю. (2005) Интерпретация образов Гамлета и Офелии в русской поэзии «серебряного века» // Новый филологический вестник. № 1. C. 56-65.

Кантемир, А. Д. (1956) Собрание стихотворений. Л. : Советский писатель. 544, [1] с.

Лавров, А. В., Гречишкин, С. С. (2004) Символисты вблизи. Очерки и публикации. СПб. : Скифия ; ИД «ТАЛАС». 400 с. 
Литературное наследство. Т. 85: Валерий Брюсов (1976) / АН СССР. Ин-т мировой лит. им. А. М. Горького. М. : Наука. 854 с.

Луков, Вл. А. (2006) Русская литература: генезис диалога с европейской культурой. М. : Изд-во Моск. гуманит. ун-та. 100 с.

Мандельштам, Н. Я. (1999) Вторая книга. Воспоминания. М. : Согласие. 364 с.

Морозов, М. М. (1954) Избранные статьи и переводы. М. : Гослитиздат. $596 \mathrm{c}$.

Некрасов, Н. А. (1981) Полн. собр. соч. и писем : в 15 т. Л. : Наука. Ленинградское отделение. Т. 1: Стихотворения 1838-1855 гг . 719 с.

Пастернак, Б. Л. (1965) Стихотворения и поэмы. М. ; Л. : Советский писатель. 730 с.

Пастернак, Б. Л. (2004) Полн. собр. соч. : в 11 т. М. : CJIOBO/SLOVO, 2004. T. IV. Доктор Живаго, 1945-1955. 760 с.

Пашкина, Н. О. (2012) «Гамлетовский» сюжет А. А. Блока: функции лирической маски // Уральский вестник. № 4. С. 214-222.

Поэзия трубадуров. Поэзия миннезингеров. Поэзия вагантов. (1974) М. : Художественная литература. 576 с.

Пушкин, А. С. (1995) Полн. собр. соч. : в 17 т. М. : Воскресенье. Т. VII: : Драматические произведения. 395 с.

Рашковская, М. А. (1992) Две судьбы (Пастернак и Дурылин. К истории взаимоотношений) // «Быть знаменитым некрасиво...»: Пастернаковские чтения. Вып. 1. М. : Наследие. 281 с. С. 235-244.

Тарановский, К. Ф. (1963) О взаимоотношении стихотворного ритма и тематики // American contributions to the Fifth International Congress of Slavists : in 2 vols. The Hague : Mouton. Vol. 2: Literary contributions. 431 p. P. 287-322.

Томашевский, Б. В. (1990) Пушкин : работы разных лет. М. : Книга. 672 c.

Федотов, О. И. (2002) Основы русского стихосложения. Теория и история русского стиха : в 2-х кн. М. : Флинта ; Наука. Кн. 2: Строфика. 484 с.

Федотов, О. И. (2011а) История западноевропейской литературы средних веков. 5-е изд., испр. М. : Флинта ; Наука. 158, [1] с.

Федотов, О. И. (2011b) Сонет. М. : РГГУ. 610 с.

Федотов, О. И. (2014) Между Моцартом и Сальери: о поэтическом даре Набокова. М. : Флинта ; Наука. 395, [1] с.

Федотов, О. И. (2016) Офелия как лирическая героиня в русской поэзии 1840-х годов (Н. Некрасов, А. Фет, Ап. Григорьев) // Острова любви БорФеда: сб. к 90-летию Бориса Федоровича Егорова) / ред.-сост. А. П. Дмитриев, П. С. Глушаков. СПб. : Росток. 1056 с. С. 917-922.

Федотов, О. И. (2017) Гамлет и Офелия как лирические герои Александра Блока // Вестник. Современный русский язык: функционирование и проблемы преподавания. № 31. Будапешт. С. 170-179.

Фет, А. А. (1959) Полн. собр. стихотворений. Л. : Советский писатель. $1051 \mathrm{c}$. 
Хайам, О. (2005) Рубайат / пер. с перс. М. : ОЛМА-ПРЕСС ; ОАО ПФ «Красный пролетарий». 256 с.

Хворостьянова, Е. В. (2008) Условия ритма. Историко-типологические очерки русского стиха / отв. ред. В. Н. Подгорбунских. СПб. : Изд-во Русской христианской гуманитарной академии. $463 \mathrm{c}$.

Ходасевич, В. Ф. (1997) Собр. соч. : в 4 т. М. : Согласие. Т. 4.744 с.

Цветаева, М. И. (1922) Конец Казановы : драматический этюд. М : Созвездие. $80 \mathrm{c.}$

Цветаева, М. И. (1965) Избранные произведения. М. ; Л. : Советский писатель. $811 \mathrm{c.}$

Цветаева, М. И. (1991) Об искусстве. М. : Искусство. 479 с.

Цветочки святого Франциска Ассизскаго (1913) / пер. А. П. Печковского ; вступ. ст. С. Н. Дурылина. М. : Мусагет. [6], XXXII, 176 с.

Шайтанов, И. О. (2003) Две «неудачи»: «Мера за меру» и «Анджело» // Вопросы литературы. № 1. С. 123-148.

Шайтанов, И. О. (2007) Дело вкуса. Книга о современной поэзии. М. : Время. $656 \mathrm{c.}$

Шекспир, У. (1960) Отелло / пер. Б. Л. Пастернака // Шекспир У. Полн. собр. соч. : в 8 т. / под общ. ред. А. А. Смирнова, А. А. Аникста ; М. : Искусство. Т. 6.687 с. С. $281-425$.

Шекспир, У. (2003а) Гамлет = Hamlet : (В поисках подлинника) / пер. И. В. Пешков. М. : Лабиринт. 165, [1] с.

Шекспир, У. (2003b) Трагедия Гамлета, принца Датского : пьеса в 3 актах / пер. А. Ю. Чернова. М. : Изографус ; Париж : Синтаксис. 350, [1] с.

Шоу, Дж. Т. (1994) Местный колорит в «Ромео и Джульетте» и сонет Мнишка в «Борисе Годунове» // Проблемы современного пушкиноведения. Псков : Псковский гос. пед. ин-т им. С. М. Кирова. 218 с. С. 5-43.

Shaw, J. Th. (1991) Romeo and Juliet, local color, and "Mniszek's Sonnet" in Boris Godunov // The Slavic and East European Journal. Vol. 35. No. 1. Spring. P. 1-35.

Дата поступления: 19.07.2018 2.

Федотов Олег Иванович - доктор филологических наук, профессор, член Союза писателей ССCР, г. Москва. Эл. адрес: o_fedotov@list.ru

Fedotov Oleg Ivanovich, Doctor of Philology, Professor, Member, Union of Soviet Writers, Moscow. E-mail: o_fedotov@list.ru

Для ичитирования:

Федотов О. И. Гамлет и Офелия как лирические герои в русской поэзии XIX-XX вв. [Электронный ресурс] // Горизонты гуманитарного знания. 2018. № 4. C. 80-142. URL: http://journals.mosgu.ru/ggz/article/view/848 (дата обращения: дд.мм.гггг). DOI: 10.17805/ggz.2018.4.6 